\title{
Escaping the middle-income technology trap: A comparative analysis of industrial policies in China, Brazil and South Africa
}

\begin{abstract}
Instead of catching up with advanced economies, most middle-income countries have remained stuck in a middle-income trap. We identify and analyse the triple challenges of 'breaking into' the global economy, 'linking up' into global value chains while 'linking back' to the local production system, and 'keeping pace' with technological change and innovation. We focus specifically on what we term the 'middle-income technology trap': specific structural and institutional configurations that are not conducive to increasing domestic value addition and to sustained industrial and technological upgrading. We explore this through case studies of China, Brazil and South Africa and the analysis of the evolution of their industrial policies and specific institutions, specifically InnoFund model in China, the Embrapa system in Brazil, and the Manufacturing Competitiveness Enhancement Programme in South Africa. Industrial policy implications for middle-income countries in particular, and for developing countries more widely, are finally discussed.
\end{abstract}

Keywords:

middle-income technology trap, structural transformation, industrial development, technology upgrading, industrial policy

JEL codes:

L6, O14, O25, O55 


\section{Introduction}

Over the past two decades, the world economy has undergone profound structural transformations. Despite a number of catching-up economies having registered fast economic growth and industrialisation in this period, world industrial production has on the whole remained highly concentrated. Today, fewer than twenty countries control $80 \%$ of world manufacturing value-addition, with similar patterns in net value addition in international trade (OECD, 2018). While a few countries - notably China - have managed to significantly expand their shares of world manufacturing production, the majority of low- and middle-income countries remain outside of this group of leading industrialised nations.

Countries that are classified in the group of middle-income countries are highly heterogeneous with respect to the structural composition of their economies, their levels of technological capabilities, and their experiences of premature deindustrialisation (Tregenna, 2009). Moreover, throughout their development history, these countries have faced different external forces, both in terms of the global industrial landscape and global policy regime. The interaction between these internal and external dynamics have shaped the different structures and trajectories of these middle-income economies (Kang and Paus, 2019).

However, if we focus our attention on the major groups of middle-income economies across the global south - South and East Asia, Latin America and Africa - we can identify important commonalities. Governments in these countries have tended to address the risks of being stuck in the so-called middle-income trap by increasingly shifting their industrial policy focus to targeted production and technology policies. More specifically, while the strategic approaches and industrial policy instruments used by these countries are different, they focus on avoiding what we call here a middle-income technology trap, that is, a specific structural and institutional configuration of the economy that is not conducive to increasing domestic value addition and to sustained industrial and technological upgrading.

We argue that a middle-income technology trap results from three main interdependent factors: first, constraints in terms of scale and technological competitiveness, and thus the challenge of 'breaking into' a persistently concentrated global industry; second, the challenges faced by domestic companies in effectively 'linking up' to global value chains (GVCs), while also 'linking back' to the domestic production system; third, the challenge of 'keeping pace' with technological change and innovation. In addressing each one of these challenges, middleincome countries can adopt different institutions and deploy different industrial policies.

This paper investigates the specific structural configuration challenges faced by countries stuck in this middle-income technology trap, and focuses on the different institutional and industrial policy responses formulated in efforts to escape the trap by three major economies- namely China, Brazil and South Africa. First, we provide a historical analysis of industrial policies in these three countries - in particular what they did in breaking into and linking up to the global economy, as well as linking back into the domestic economy. Against this historical background analysis, we then focus on the specific turning point at which specific institutions and policies have been introduced and implemented to address the challenge of keeping pace with technological change and innovation. To address this specific challenge, middle-income countries need targeted investments to develop production, technological and innovation capabilities across different 'technology types' and along different 'stages of technological development' - from research to technology scaling-up, commercialisation, and effective deployment in production operations. 
We claim that, given the weaknesses in the national industrial and innovation systems of middle-income countries, these different stages of technological development can be hampered by several investment gaps. Our country cases show that these investment gaps can be addressed with different policy responses. Specifically, we discuss (i) the 'funding innovation model' and hybrid financial solutions, focusing on the early stages of technological innovation adopted under the InnoFund model in China; (ii) the 'intermediate technology institution' model supporting product, process and technology scaling-up stages adopted under the Embrapa system in Brazil; and (iii) the 'matching grant commercialisation' model of the Manufacturing Competitiveness Enhancement Programme, focusing on the later stages of technology absorption and development in South Africa.

These institutional solutions and policy instruments are embedded in different industrial policy packages that have evolved from specific structural and political economy dynamics (Andreoni and Chang, 2019; Chang and Andreoni, 2020). Drawing on an in-depth analysis of the specific design, implementation and enforcement mechanisms adopted by these countries, the paper finally provides a comparative analysis of these alternative models, with a focus on their effectiveness and governance challenges. In the comparative analysis, we situate these different institutional solutions and policies against technological readiness levels (TRLs), a metric widely used among high-income and some middle-income countries to characterise different stages of technological development. We show how lessons from these three major schemes in three of the so-called BRICS countries can be applied to other countries that are similarly affected by (or are in the process of approaching) a 'middle-income technology trap'.

2. Middle-income trap? Towards a structural understanding of the industrialisation challenges of middle-income countries

\subsection{The 'middle-income trap'}

The world's middle-income countries (MICs) are a heterogeneous group of more than 200 countries that are home to five billion of the world's seven billion population (and $73 \%$ of the world's poor people) and generate half of global GDP (World Bank, 2018). Among the 101 economies classified as 'middle-income' in 1960, only 14 had become 'high-income' by 2008 (World Bank, 2013). This group includes Ireland and the Southern European countries, the fast industrialising tigers of East Asia, and a few small resource-rich countries in Africa. Not only did so few countries manage to graduate to high-income status, in recent years a number of middle-income countries have witnessed a slowdown in their economic growth after reaching middle-income levels.

The concept of the 'middle-income trap' was introduced in a research report by the World Bank, titled An East Asian Renaissance: Ideas for Economic Growth. In this report, Gill and Kharas (2008:18) discuss the idea of the middle-income trap:

In the absence of economies of scale, East Asian middle-income countries would face an uphill struggle to maintain their historically impressive growth. Strategies based on factor accumulation are likely to deliver steadily worse results, which is a natural occurrence as the marginal productivity of capital declines. Latin America and the Middle East are examples of middle-income regions that, for decades, have been unable to escape this trap (italics added).

Despite the term 'middle-income trap' itself remaining largely under-theorised (see, for instance, Felipe et al., 2017; Bresser-Pereira et al. 2020), it has since been used widely in the 
development literature and policy discourse to describe stagnant growth in both absolute and relative terms. It suggests a situation of a long-term, stagnating equilibrium in terms of per capita income, and thus failure to maintain sustained economic growth and catch-up towards the high-income level of developed countries. For example, Arias and Wen (2015) define an 'income trap' as the phenomenon of an economy's aggregate income per capita failing to grow faster than that of the United States (US), which is taken as the benchmark for the developed world. A situation in which an economy's income per capita relative to the US remains constantly and substantially below $50 \%$ is denoted a (relative) middle-income trap. Gill and Kharas (2008) refer to a (relative) low-income trap (or poverty trap) in cases when it remains significantly below 10\%. Felipe (2012) provides a working empirical definition of the middleincome trap, with the results suggesting that a country attaining lower middle-income status must grow at least $4.7 \%$ per annum on average to avoid being caught in a trap, with the corresponding rate for upper middle-income countries being $3.5 \%$.

A growing literature has attempted to understand the middle-income trap and its global structural dynamics (for reviews, see Kang and Paus, 2019; Wade, 2016). Among them, a number of specific industrialisation challenges faced by middle-income countries have been identified. For example, scholars have pointed to the challenges that middle-income countries face in sustaining sufficiently high rates of labour productivity growth over a long period of time. From this perspective, Justin Lin (2017:6) suggests that "[ $t]$ he middle-income trap is a result of a middle-income country's failure to have a faster labor productivity growth through technological innovation and industrial upgrading than high-income countries".

Along similar lines, but with a focus on global competitive dynamics, other scholars (see, for instance, Lee, 2013; Lee and Ramanayake, 2018; and the empirical review by Im and Rosenblat, 2013) argue that a source of the middle-income trap is the difficulty of these countries to gain space in the global market. Competing with low-wage and large-scale exporters presents a fundamental challenge, given their lower price competitiveness in terms of wages and scale-efficient production. For middle-income countries that have reached relatively large-scale production, competition with technologically advanced economies is difficult because their industrial capabilities are not yet sufficiently developed to give them a competitive advantage.

Other scholars have linked the middle-income trap to premature deindustrialisation in middleincome countries (Andreoni and Tregenna, 2019). Premature deindustrialisation represents a major threat to developing countries' prospects of sustained catching up. The reason for this is that, by shrinking their manufacturing base, premature deindustrialisation reduces opportunities for the development and accumulation of technological capabilities and, as a result, countries' capacity to add value in GVCs and tradable sectors, and their scope for innovation and productivity growth. Where a country's manufacturing sector is underdeveloped or has shrunk through premature deindustrialisation, this undermines its ability to sustain productivity growth at the rates required for catching up.

Political scientists have recently emphasised the role that institutions and interests play in different political economy contexts in addressing middle-income challenges. Doner and Schneider (2016) emphasise institutional co-ordination and the emergence of upgrading coalitions as central for escaping the middle-income trap. Sen and Tyce (2019) point to the relationship between the state and business in the case of Malaysia and Thailand, and how the patronage-based relationship has affected their technological upgrading. Finally, KlinglerVidra and Wade (2019) focus on the gaps in national innovation systems and entrepreneurship 
to explain the challenges faced by Vietnam in its upgrading, while Doner and Schneider (2019) have documented the challenges faced by Malaysia in developing its technical and vocational education system to escape the middle-income trap.

The literature on the middle-income trap thus points to several industrialisation challenges that are intertwined and that reinforce each other in different ways along different countries' structural, institutional and political economy trajectories. These challenges also present potential opportunities for middle-income countries to industrialise and develop. Capturing these opportunities is conditional, however, on appropriate institutional and policy responses.

In the analysis that follows, we suggest the need to go deeper in our understanding of these industrialisation challenges by considering the specific structural factors responsible for the middle-income trap. We argue that there are three key challenges - 'breaking into', 'linking up and back' and 'keeping pace' - which we discuss further below. Against this analytical background, we focus in the following sections on specific institutional and policy responses adopted by different middle-income countries, and assess the extent to which the selected countries have managed to turn these challenges into opportunities for technological upgrading.

2.2 Breaking into: Global concentration, compression and reconfiguration of manufacturing production

Over the last two decades, the global industrial landscape has been reshaped by profound structural transformations and the shifting around geographically of manufacturing production. These dramatic transformations started in the mid-1990s and led to the 'great convergence' between the most industrialised nations and a relatively small group of economies that were catching up fast. Between 1995 and 2010, the G7 countries lost significant shares of value addition. In particular, their shares in world manufacturing value added (WMVA) registered a major decline. In 1995, the two leading industrial nations - the US and Japan - together contributed more than $40 \%$ of WMVA, while Germany, Italy, France and the United Kingdom (UK) contributed another $25 \%$. South Korea and Canada each controlled another $2 \%$ of WMVA at that time. This means that fewer than ten nations controlled more than $70 \%$ of world manufacturing in 1995. By 2011, less than 15 years later, all the G7 countries together accounted for only $40 \%$ of the WMVA, although their manufacturing value added in absolute terms kept increasing steadily until the 2007 financial crisis.

During the same period (between 1995 and 2010), a group of emerging economies more than doubled their joint WMVA shares from $18 \%$ to $36 \%$ (Figure 1$)^{1}$. This process of convergence has been driven by the rise of the new industrial superpower - China - and a group of fast catching-up economies. China moved from contributing less than 5\% of WMVA in 1995 to $10 \%$ in 2005, and more than $20 \%$ in 2011, reaching almost $23 \%$ in 2014 . As a result, China's share in world value-added exports surged to $17 \%$ in 2014 , seven percentage points ahead of the second world-leading exporter - Germany - and more than double that of the US. Between 2000 and 2010, India, Russia and Brazil almost doubled their WMVA shares to pass the 2.5\% threshold, while Indonesia approached almost $2 \%$ by 2010. As can be seen in Figure 1, the rest of the 'top 16' (excluding the G7) significantly grew its manufacturing production over this

\footnotetext{
${ }^{1}$ Figure 1 shows data from TiVA OECD 2016 edition, which covers the period 1995 to 2011 . While the updated TiVA OECD 2018 edition extends to 2014, it has a shorter overall timespan and only goes back to 2005, missing the previous decade, in which the impact of the rise of China is apparent. The same applies to Figure 2, which goes up to 2011 .
} 
period. However, a number of middle-income countries, including South Africa, were only marginally involved in this great convergence, as reflected in their WMVA shares.

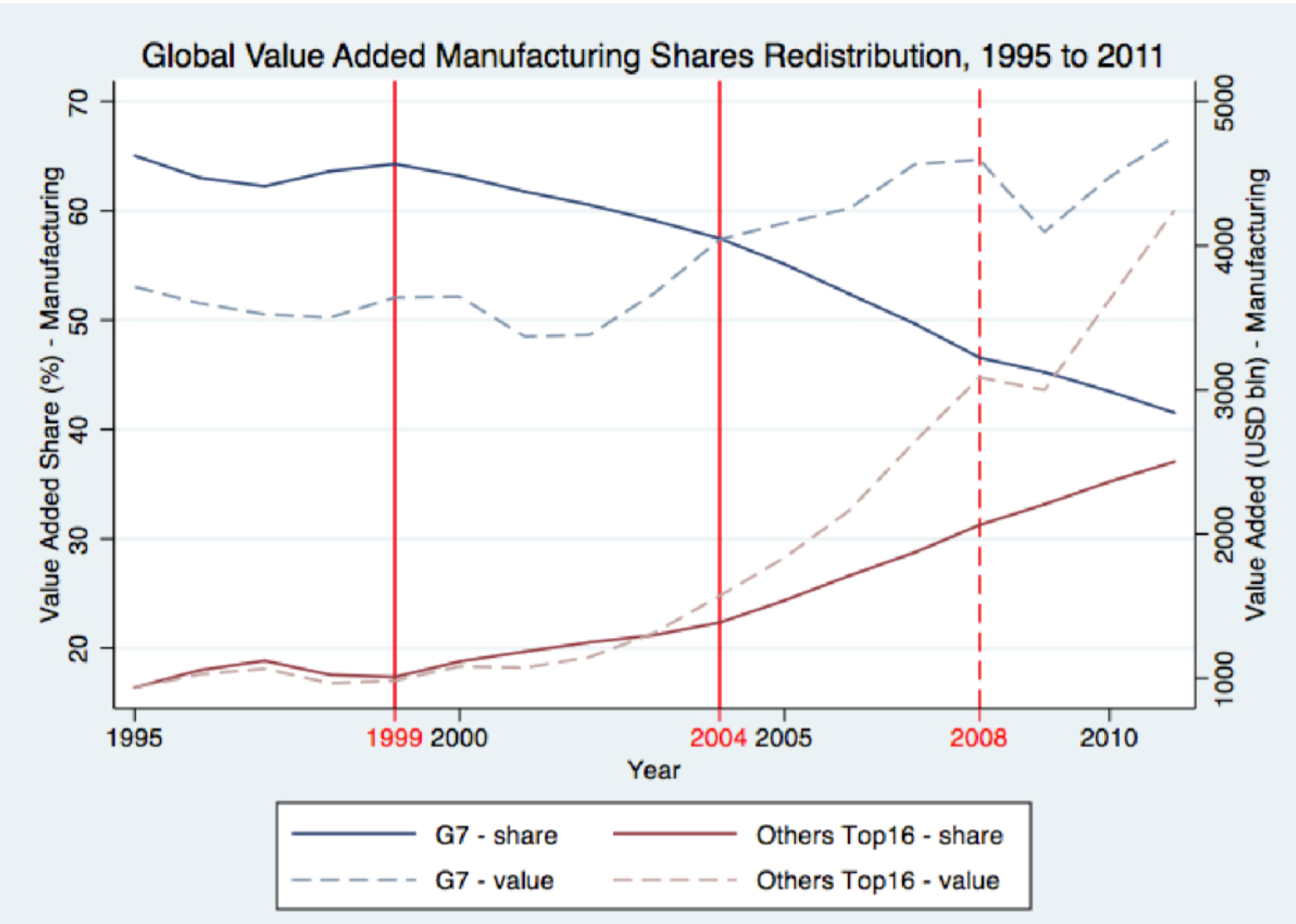

Figure 1: The great convergence and global concentration

Source: Authors, based on TiVA OECD

Note: "Others Top16" includes countries other than the G7 that were in the top 16 for manufacturing value added in 2011: China, Korea, Brazil, India, Russia, Indonesia, Mexico, Spain and Turkey.

Taken together - G7 plus the rest of the 'top 16' shown in Figure 1 - only 16 countries accounted for $80 \%$ of the world total MVA in 2011. We thus see an ongoing concentration of manufacturing production amongst a relatively small group of countries, combined with a reconfiguration of those shares. The G7 countries no longer command the same high share of global manufacturing as was previously the case, due to the rise of China and a relatively small group of emerging industrial economies, yet the G7 share remains high. The next tier of emerging manufacturers - shown here as the group of 16 - has to some extent closed the gap with the advanced economies in a number of economic sectors. However, even this emerging group of countries is itself highly concentrated, and the development of one country in one sector tends to lead to a fast process of global concentration. We have indeed entered what some scholars have called a phase of 'compressed development' (Whittaker et al., 2020). ${ }^{2}$

\footnotetext{
2 See also Haraguchi et al. (2017) on the shifting patterns of manufacturing internationally, in which manufacturing activities have become increasingly concentrated in a small number of populous developing countries.
} 
We thus see the persistence of concentration, but in a reconfigured form, along with compression. On the one hand, the success of the rest of the 'top 16' in 'breaking in' demonstrates the possibilities of industrialisation and of eating into the share of the advanced economies. On the other hand, global manufacturing production remains concentrated and compressed, with most middle-income countries failing to break in, and in fact experiencing deindustrialisation.

This persistent concentration and compression in global manufacturing - both at the country and sectoral levels - have made it very difficult for middle-income countries to break into medium- and high-tech production activities. Barriers to this breaking in - that did not face earlier industrialisers (or at least not to the same extent) - include realising global-scale economies, intellectual property rights, institutions and capabilities for technological development and innovation. The emergence of major national champions and multinational companies operating globally has also introduced new forms of direct and indirect (via global supply chains) competition in middle-income countries' domestic markets. The very success of countries such as China, with their large markets and ability to realise economies of scale, and effective institutions and policies (as discussed further below), simultaneously opens up some opportunities for other middle-income countries, and makes their own route to industrialisation and structural transformation more difficult.

\subsection{Linking up and back: Global value chain integration and domestic value addition}

GVC upgrading is the process of improving the ability of a firm or an economy to move to more profitable and/or technologically sophisticated capital- and skills-intensive economic activities - higher value-creation potential - and capture the value created from them. Upgrading can take different forms of 'linking up', including: (i) Process upgrading, which typically refers to improved production methods that transform inputs into final products more efficiently through the reorganisation of production or the introduction of superior technology; (ii) Product upgrading, which is moving into more sophisticated product lines in terms of higher unit-value products, rather than moving to a different part of the value chain; (iii) Functional upgrading, which involves performing new, superior functions in the chain, such as design or marketing, or abandoning existing low value-added functions to focus on higher value-added activities; and (iv) Intersectoral upgrading, which entails applying the competence acquired in a particular function or industry to move into a new sector (Ponte et al., 2019).

The GVC framework stresses the opportunities for companies to specialise in specific production tasks or components, preferably 'high-value niches', while avoiding the building up of entire vertically integrated industrial sectors or blocks of industries (Gereffi, 2013; Milberg and Winkler, 2013). The idea of a selective form of specialisation in tasks, driven by capturing value opportunities, would encourage companies to upgrade incrementally towards activities such as research and development (R\&D), design and downstream post-sale services.

First-tier suppliers and original equipment manufacturer (OEM) companies in middle-income countries, however, face multiple challenges in linking up to the GVC, especially moving into more technologically sophisticated segments of GVCs. First, focusing on the production of low-value-added parts and components does not automatically lead to the upgrading of domestic technological capabilities, especially given the endogenous asymmetries characterising GVCs (Andreoni, 2019; Milberg and Winkler, 2013; Raj-Reichert, 2019) and the higher capability threshold that companies have to reach to engage with digital production 
technologies . Moreover, in a number of cases, middle-income countries that have attempted to integrate globally have also ended up 'de-linking domestically' and hollowing out the domestic manufacturing sector. Under these conditions, a combination of weak productivity growth and rising labour costs, or the emergence of alternative lower-cost locations, might lead to declining profitability, disengagement by the lead firm and a further weakening of domestic productive capacity.

In contrast, by linking up to international companies and system integrators while 'linking back' to local producers and local supply chains - local production system development domestic companies can capture international demand and learn from exporting (Andreoni, 2019). South Korea and Taiwan between 1970 and 1990, and China in the 1980s and 1990s, all started their industrialisation by linking (backwards) to global supply chains and adding value (forwards) in electronics and other industries, starting in particular from those characterised by short technology cycles (Lee, 2013). With the expansion of the local production system, more opportunities for backward integration also open up, as domestic companies start importing more intermediate goods while diversifying their export baskets. Lee et al. (2017) describe this successful catching-up process as an 'in-out-in-again' model of integration into GVC.

Over the last two decades, a very small number of middle-income countries have been successful in linking up while linking back. That is, only a few of them have managed to involve OEMs, and first-, second- and third-tier domestically located companies in valuecreation processes. Thus, domestic value-added performances reflect the extent to which countries have been able to build up their technological capabilities and take advantage of the opportunities offered by forward integration into GVCs. ${ }^{3}$ While the value of world imports more than doubled during the 2000s, and with intermediate goods making up $65 \%$ of world imports in 2011, backward integration in GVCs among major middle-income countries was not very successful between 1990 and 2010.

Figure 2 presents domestic value-added performances across a range of major middle-income countries, showing the diversity of GVC integration trajectories. China presents a unique case among these countries, having managed to increase its backward integration (measured in terms of foreign value added (FVA) in trade) by linking up globally in the 1990s, and then increase its domestic value addition by linking back domestically throughout the 2000s. In contrast, South Africa has seen a steady increase in foreign domestic value added in trade (despite its export basket being skewed towards minerals) throughout the 1990s and 2000s. Brazil can be seen as an intermediate case, with moderate growth in FVA (i.e. decline in DVA) during the 1990s, followed by the proportions of FVA and DVA remaining roughly constant on average over the 2000s.

\footnotetext{
${ }^{3}$ DVA measured as $(1$ - FVA) in manufacturing products captures the extent to which a country is able to add value to its products. The value addition can be the result of several types of activity, including extracting and processing raw materials; designing a product; producing components; integrating or assembling product systems; and adding services to products downstream in the value chain. To capture the extent to which a country has engaged in value-addition activities, it is critical to measure only net value addition, thus excluding the value that results from buying goods and services from abroad.
} 

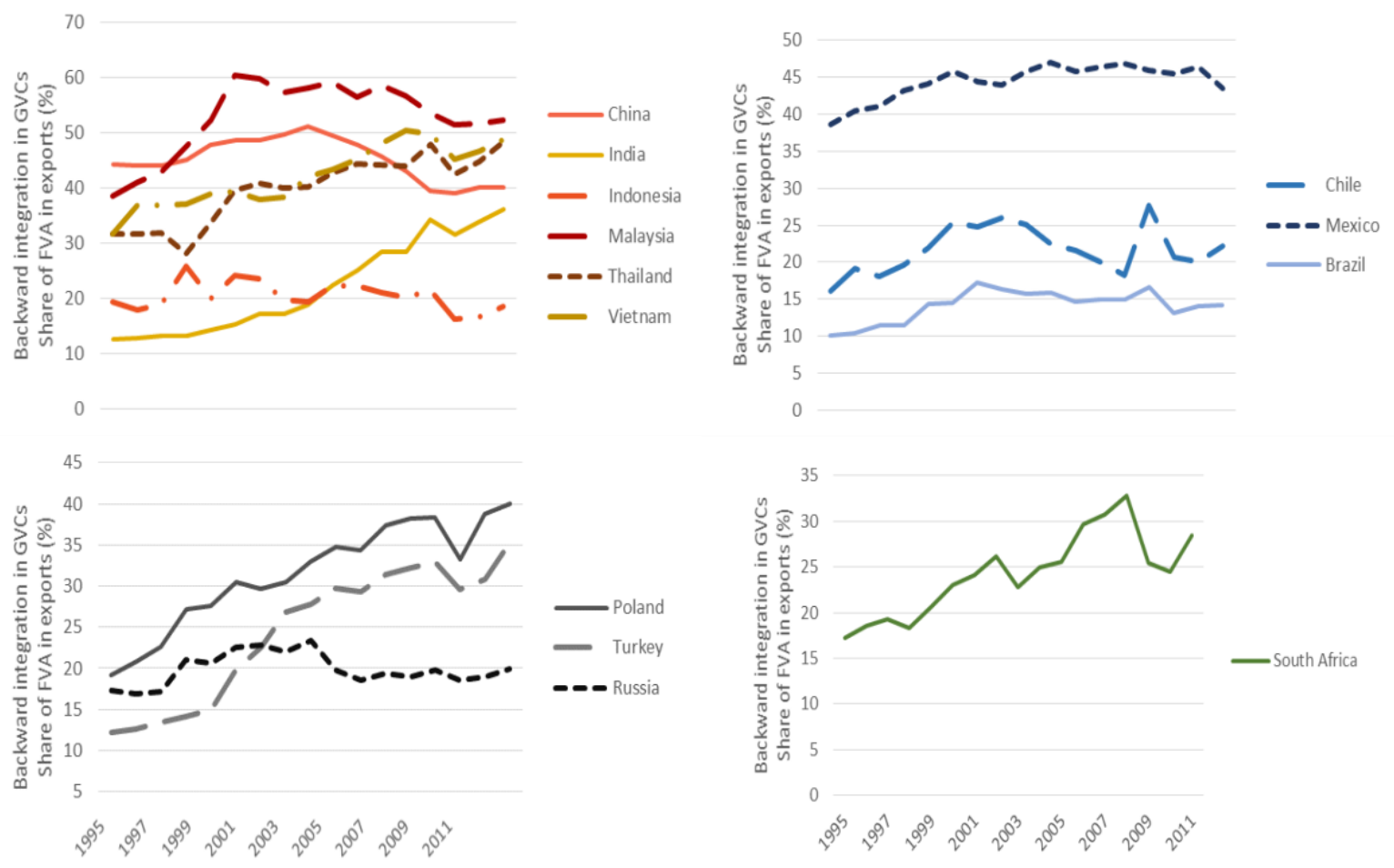

Figure 2: Backward integration in GVCs among major middle-income countries Source: Authors, based on TIVA

The different levels of performance in value addition discussed above are thus the result of a specific structural configuration of the production system of middle-income countries - their sectoral/task specialisation and the weakness of their domestically located supply chains. Opportunities for value addition - both value creation and value capture - are unevenly distributed across different sectoral value chains. However, they generally reflect the technological capabilities involved in production (Andreoni and Tregenna, 2019; Chang and Andreoni, 2020). This means that, in order to link up and back successfully, middle-income countries have to address a fundamental problem of technological upgrading. And they have to do that fast enough to overcome the so called 'Red Queen Effect' - that is, the fact that "middle income countries have to move to innovation-based growth more quickly, just to stay in the same place, let alone move up" (Kang and Paus, 2019:3).

\subsection{Keeping pace with technological change and innovation}

In a concentrated and GVC dominated industrial landscape, keeping pace with technological change and innovation is a twofold challenge for middle-income countries. The reason is that their investments and capability building efforts need to target both the development of different 'types' of technologies as well as different 'stages' of technological development. We consider each of these in turn.

First, countries need to develop technological capabilities across different 'technology types', as different types of technologies are required to absorb and adapt foreign technologies as well as to produce and innovate on them. For example, developing generic technologies is not sufficient if their development is not complemented by other types of technologies which translate them into products for the market. 
Tassey (2007) distinguishes at least three types of technologies. First, there are 'proprietary technologies', which generally are associated with specific products (e.g. a certain machine, or a critical component of a sophisticated product system, for instance the membrane of a medical device or the mechatronic system underpinning a robotic solution) or industrial transformation processes (e.g. a certain chemical process that allows the production of a composite material for the aerospace industry). The latter type of proprietary technologies used in industrial processes are also called production technologies (e.g. robots performing laser welding in the automotive industry).

Proprietary technologies are generally developed by companies - private or state-owned enterprises (SOE) - that are operating in one or more markets with their own brands or as OEMs or suppliers. However, despite their commercial differences, they are all based on a set of 'generic technologies' that emerge from the science base of one or more countries, their universities, industrial research centres and laboratories, or military and health system institutions. Large private companies are also involved in the development of some of these generic technologies, often in collaboration with government-funded institutions or relying on public funding and grants.

The development of these different types of generic and proprietary technologies, including production technologies, often requires companies and other institutions to have access to 'infra-technologies' (Link and Scott, 2011). Historically, the quasi-public-good nature of these technologies makes the involvement of government institutions in the funding and provision of/access to these technologies natural. Moreover, while some of these infra-technologies are relatively inexpensive, others are prohibitive for small companies and, in some cases, can operate only under an open system and a regulated model. Thus, there are different types of technologies and different private and public players can be - and historically across countries have been - involved in their development (Block and Keller, 2009).

Second, investments in these technological capabilities need to be carefully allocated along different 'stages of technological development' - from research to technology scaling-up, commercialisation, and effective deployment in production operations - and have to be significant enough to compete globally. For example, a country with investments concentrated in basic research only, will find it difficult to scale up technological innovation.

Technological development follows different stages and can be measured in different ways (Hall and Rosenberg, 2010). Traditionally, scholars have distinguished five stages of technology development - research, concept/invention, early-stage technology development, product development, and production/commercialisation. Borrowing from the aerospace industry, other scholars and policymakers have, over the last two decades, increasingly relied on a more granular technology metric called 'technological readiness levels' (TRLs) (Mankins, 2009). The TRL metric focuses on the technology innovation development stages and makes it possible to assess the extent to which technologies (e.g. machinery, equipment or software) are ready to be deployed in production in an operating plant. TRLs comprise a nine-point scale based on a qualitative assessment of maturity, clustered around four main phases: research (TRL 1-3), development (TRL 4-6), deployment (TRL 7-8) and operations (TRL 9).

As shown in Figure 3, among industrially advanced western economies, the TRL metric has been especially used to draw attention to what has been called a 'valley of death' represented by potential investment gaps in technology development stages TRL 4-5-6. Indeed, in advanced economies, governments tend to invest heavily in research - at least comparatively 
- and firms are typically keen to invest in technologies that have proven to be deployable and ready to the market. Not only is this valley larger in middle-income countries, that is, several stages of technology development are underfunded (horizontal arrow), but moreover those stages in which the government or the private sector invests tend to be funded at lower levels (vertical arrows). The combination of these two dimensions make keeping pace with technological change and innovation particularly challenging for middle-income countries.

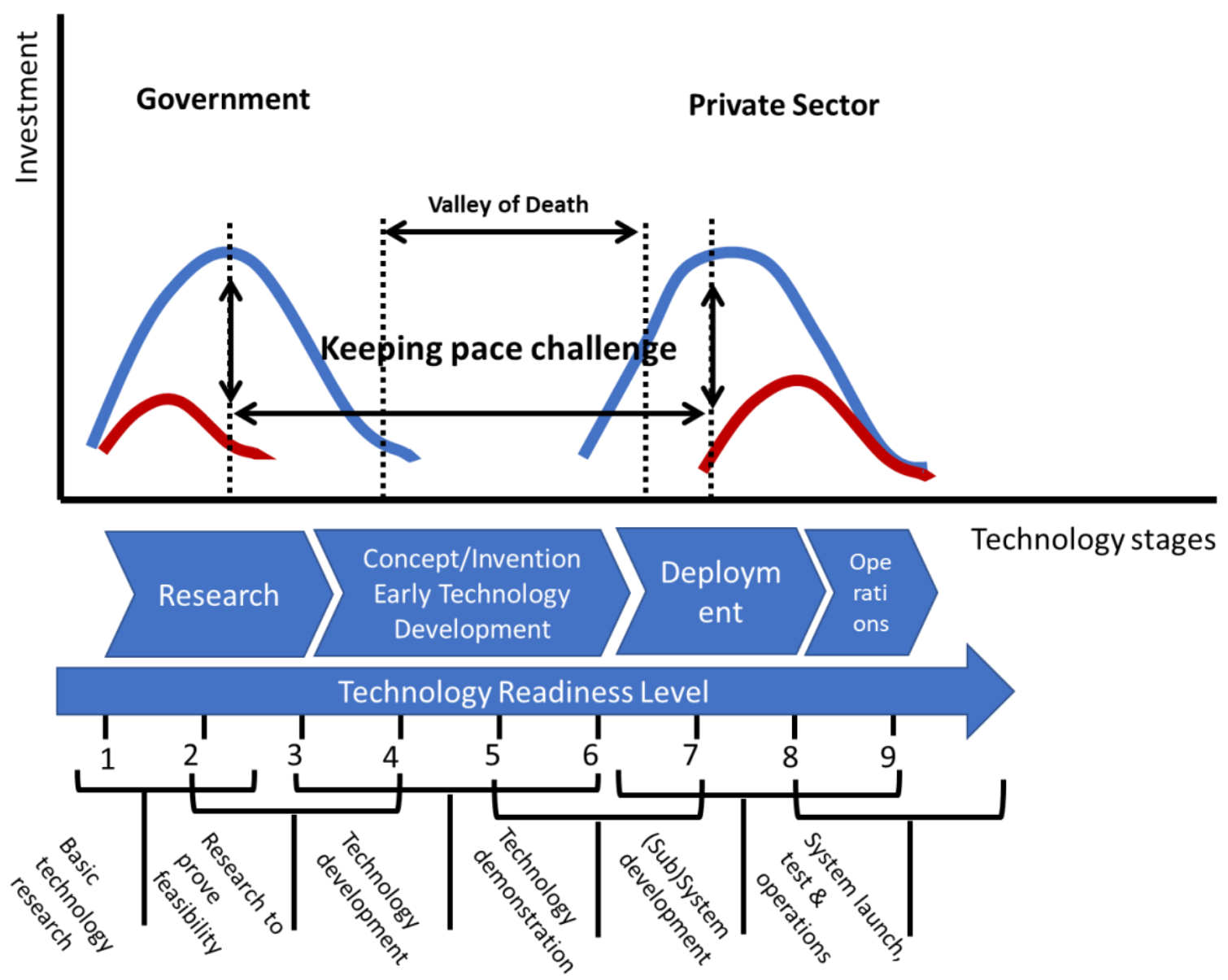

Figure 3: Keeping pace with technological change and innovation challenge Source: Authors

The reasons why middle-income countries tend to be in a weaker position when it comes to keeping pace with technological change and innovation has to do with two aspects. First, the government tends to have a much lower investment capacity in basic science relative to leading industrial nations. As a result, firms in middle-income countries might not be able to leverage a well-funded and diversified domestic science base that provides access to generic technologies. Companies are also unable or unwilling to make significant investments in basic research, as the long-term capital commitment is prohibitively high and/or too risky. The fact that the industrial base in these countries has limited diversification and technological depth also means that the scaling up of the new product or technology has to rely on external inputs. For instance, production technologies are designed and produced abroad, so middle-income countries mainly use expensive foreign technologies. Finally, the technological weakness and 
fragmentation of the domestic production system means that access to infra-technologies tends to be limited to private companies.

Many of the specific challenges associated with keeping pace with technological change and innovation are intrinsically linked to the other two set of challenges discussed above, that is, breaking into global markets and linking up into GVC while developing domestic production systems. The combination of these three set of challenges - what we have called the middleincome technology trap - can be addressed with different industrial policies and institutions. For example, governments can rely on fiscal incentives and subsidies in the form of research grants to support firms' investments in research and technological upgrading. Another option is to provide technology services - thus, non-financial incentives - to overcome access to specific capabilities that companies in middle-income countries might be missing. Each of these choices potentially determine the effectiveness of industrial policy in overcoming the middle-income technology trap.

\section{Industrial policies in middle-income countries: China, Brazil and South Africa}

In this section, we investigate the specific strategies followed by three major middle-income countries from three geographic regions: China, Brazil and South Africa. These countries have followed very different structural trajectories and have engaged with the specific challenges of breaking into, linking up (and back), and keeping pace highlighted above at different points in time, with different policies and institutions, and with different outcomes. Figure 4 shows the contrasting economic trajectories of the three countries over time. Brazil and South Africa both held upper-middle-income status throughout this period, apart from Brazil during the years 2002 to 2005 and South Africa during the years 1998 and 2001 to 2003, in which they were classified as lower-middle-income countries. China, by contrast, began this period as a lowerincome country, first reaching lower-middle-income status in 1997 and continuously from 1999 onwards, ascending to upper-middle-income status from 2010. Stark differences between the three countries are apparent in terms of MVA per capita. In China, MVA per capita grew faster than GNI per capita over this period, in contrast to the deindustrialisation evident in both Brazil and South Africa. China ended the period with MVA per capita far above that of the other two countries. Overall, the picture is one of industrialisation and dynamic growth in China, with deindustrialisation and stagnation in Brazil and South Africa. 


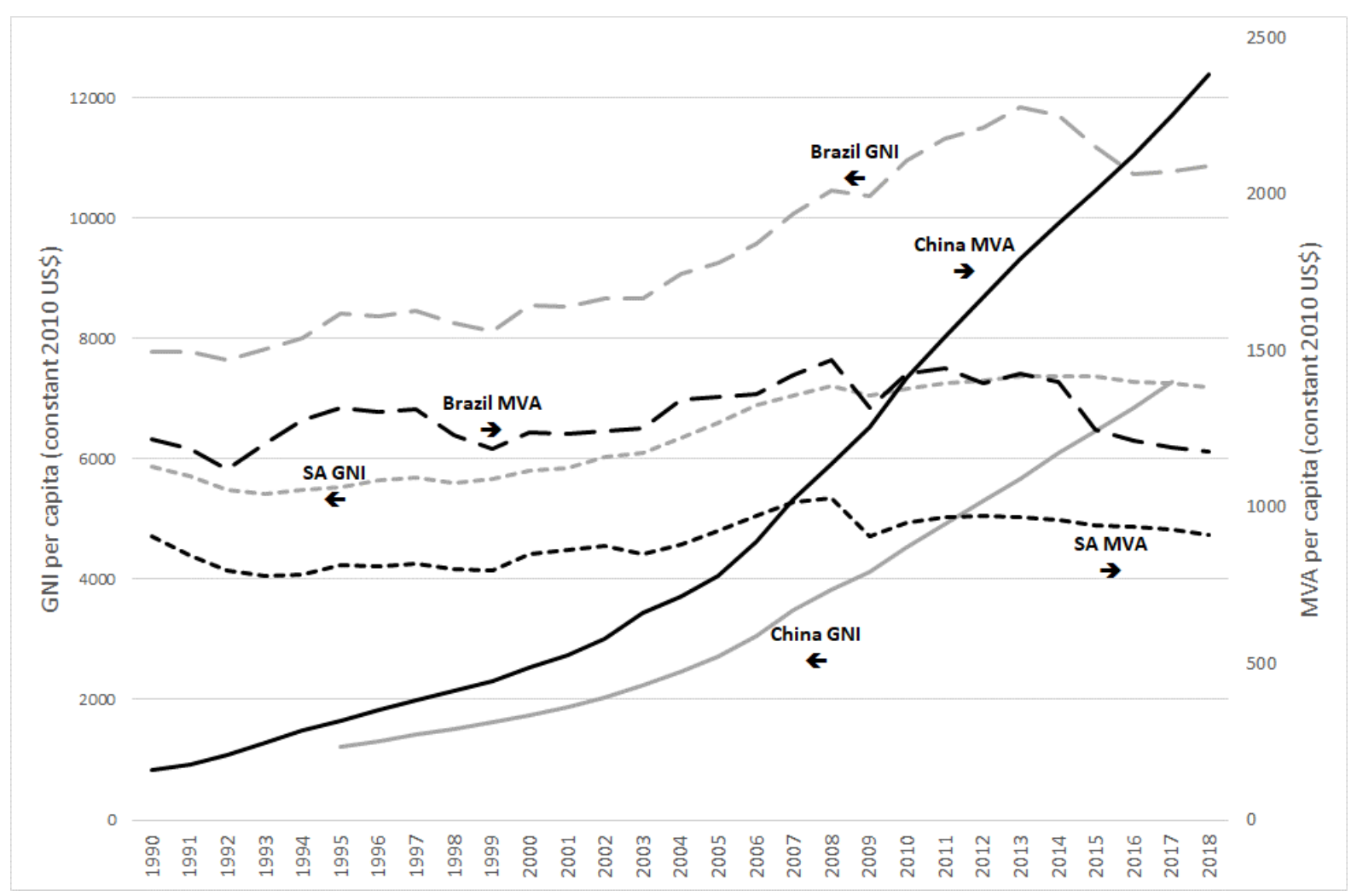

Figure 4: GNI and MVA per capita in China, Brazil and South Africa, 1990 to 2018

Notes: GNI per capita (in constant 2010 US\$) is depicted in grey, with values on the left-hand axis. MVA per capita (in constant 2010 US\$) is depicted in black, with values on the right-hand axis. China is shown in solid lines (GNI data only available for 1995 to 2017); Brazil is shown in long-dashed lines and South Africa in dotted lines.

Source: GNI per capita from World Bank World Development Indicators, MVA per capita calculated from UNIDO INDSTAT

\subsection{China}

Since the late 1970s, industrial policy has been an integral part of China's five-year planning. In 1989, the concept of industrial policy was explicitly mentioned for the first time in an official document (the State Council's paper, Decision on Current Industrial Policy Priorities). This was followed in 1994 by the more comprehensive and integrated Outline of State Industrial Policies for the 1990s, which emphasised the development of mainstay and high-technology industries, and the need to readjust the composition of foreign trade by strengthening manufacturing competitiveness. Many initiatives and policy measures, especially in the early period, were inspired by the successful experiences of Japan and Korea and focused on breaking into the global economy by linking up to value chains. The Sixth Plan (1981 to 1985) marked a more outward-oriented approach, focusing on importing technologies and developing endogenous technological and innovation capabilities. Thus, since the 1980s, China started using several policy instruments to link back and develop linkages to the local production system and keep pace with technological change.

\subsubsection{Breaking into, linking up and back}

China is the most successful country in the process of great convergence that started from the mid-1990s, as measured in WMVA shares (see section 2). China's successful breaking into the 
global market resulted from a first phase of linking up to global value chains, followed by an incremental process of linking back to and technological upgrading of the domestic production system. To achieve these complementary sets of goals, China adopted a selective approach to industrial policy. Strategic industries, or 'pillar industries', were identified based on their importance to China's national security and economy (e.g. defence, coal, electric power, telecommunications, petroleum and petrochemicals, civil aviation and shipping) and growth potential (e.g. alternative-fuel cars, biotechnology, environmental and energy-saving technologies, alternative energy, advanced materials, new-generation information technology, and high-end equipment manufacturing).

Achieving industrial competitiveness in these strategic industries, and thus becoming capable of breaking into global markets and value chains, relied heavily on the development of a 'national team' of state enterprises and the strategic use of trade policies (Nolan, 2001; Sutherland, 2003). SOEs played a critical role in co-ordinating processes of industrial upgrading and restructuring, in some cases limiting domestic competition to achieve economies of scale and overcome entry barriers. SOEs benefited from incentives and preferential loan terms. Between 1998 and 2003, SOEs received 65\% of all commercial bank loans, despite accounting for only a quarter of China's economy (Ferri and Liu, 2010:54). Imputed interest rates on debts offered to SOEs were $20 \%$ to $25 \%$ lower than those offered to private enterprises between 1999 and 2003 (Ferri and Liu, 2010:55).

Each targeted sector also received a package of complementary industrial policy measures, including tariff and non-tariff barriers, import quotas, local content requirements, licencing systems, tax exemptions, subsidised land, and subsidised loans from state-owned policy banks. Firms from prioritised industries benefited from subsidised loans from development banks, such as the Export-Import (Exim) Bank of China, the Agricultural Development Bank of China (ADBC), and the China Development Bank (CDB). The overall financial infrastructure was also given a pro-industrial development orientation by law ${ }^{4}$.

The development of an industrial base was also made possible by a strategic engagement with leading foreign companies controlling global value chains. Foreign direct investment (FDI) policies were widely used by China in linking up to global value chains while creating the conditions for the development of domestic production linkages. The June 1995 Provisional Regulations of Guidance on Foreign Direct Investment mapped out guidelines for targeting FDI in desired high-technology sectors, and a list of encouraged, restricted or prohibited foreign investments was recorded in the Foreign Investment Industrial Guidance Catalogue. Targeted industries typically involved high-end manufacturing, new and advanced technologies, energy efficiency and environmental protection. The automobile and semiconductor industries, for example, were guaranteed market protection in exchange for technology transfer, while increases in companies' production scales were reached through government-led mergers and acquisitions (Lo and $\mathrm{Wu}, 2014$ ).

Linking back into the domestic production system and promoting its technological upgrading were achieved by steering industrial consolidation and strategic mergers and acquisitions among domestic firms, as well as encouraging joint ventures with foreign companies. To facilitate technological transfers from more advanced economies, China offered tax incentives

\footnotetext{
${ }^{4}$ For instance, Chapter IV, Article 34 of the 1995 Law of the People's Republic of China on Commercial Banks indicates that "[a] commercial bank shall conduct its loan business in accordance with the need for the development of the national economy and social progress and under the guidance of the state industrial policy" (for a discussion, see Andreoni, 2016).
} 
to entice foreign companies to establish $\mathrm{R} \& \mathrm{D}$ centres, and imposed technology-import regulations and ownership restrictions. To conform to the ownership restrictions, transnational corporations (TNCs) formed joint ventures with Chinese companies. Such joint ventures ultimately allowed the state to retain effective control over foreign affiliates so as to advance Chinese interests (Roehrig, 1994). The development of the local production systems also relied on cluster policies, as well as export-promotion zones. For example, the Innovation Clusters programme was aligned with the development of National High-Tech Zones (NHTZs) and Special Economic Zones (SEZs).

China's automobile industry offers an example of a sector that benefited from this complex package of industrial policies. Before the 1980s, the automotive industry comprised largely of SOEs, including First Automobile Works (FAW), Beijing Automotive Industry Corporation (BAIC), Dongfeng Motor Corporation, and Shanghai Automotive Industry Corporation (SAIC). In the 1980s, the automotive industry was identified as one of China's pillar industries for driving its economic development. Although foreign investors benefited from tax exemptions and subsidised land, they were highly regulated, with local content requirements and joint venture rules with indigenous firms (foreign shareholding was capped at 50\%). Examples of early joint ventures include BAIC and American Motors Company, and SAIC and Volkswagen. Import tariffs and quotas were imposed using an infant industry strategy, with import tariffs as high as $200 \%$ to $300 \%$ in the 1980 s, and $100 \%$ to $200 \%$ in the early 1990 s (Huang, 2003:260). It was only in the late 1990s that the government loosened entry restrictions on foreign automobile manufacturers.

The market liberalisation agenda in the second part of the 1990s brought various changes in Chinese industrial policy efforts. Agriculture, infrastructure, construction and services were included in the list of pillar industries. The Tenth Five-Year Plan (2001 to 2005) marked renewed systemic industrial and technology policy efforts. A number of other policy measures have been introduced since 2005 as part of subsequent five-year plans. The policy model has increasingly relied on the involvement of provinces and municipalities. Policy co-ordination is achieved through the National Development and Reform Commission (NDRC), which drafts industrial plans for the State Council but also collates inputs from the Communist Party of China (CCP) Central Committee, and provincial and municipal governments (Dorn and Cloutier, 2013).

As a result of this accelerated process of structural change and the new industrial policy approach, China has entered a path of indigenous innovation (zizhu chuangxin). Berger (2013:145) shows that, until 2005, there was limited evidence of domestic innovation capabilities. Thereafter, companies in high-tech sectors developed enhanced capabilities (increasingly mastering the scale-up of complex system products and processes, translating into advanced product design and advanced manufacturing, and reducing the time to the market). Companies have also developed redesign, reverse and re-engineering competencies (re-assembling foreign components, changing functions and materials, and product characterisation). Thus, these companies are increasingly able to produce products with 'Japanese [good enough] quality at Chinese prices', making them striking examples of the success of China's new industrialisation policies.

\subsubsection{Keeping pace: The innovation funding model and the case of InnoFund}

Since the 1980s, China has adopted several technologies and R\&D-financing policies to keep pace with technological change. In 1986, the National High-Tech Development Plan (also 
known as the 863 Plan) introduced the first articulated national technology strategy targeting biotechnology, space, information technology, laser technology, automation, energy and new materials. This technology plan was updated over time to include emerging technologies, such as telecommunications (1992) and marine technology (1996). The Torch Programme was initiated in 1988. It promoted (i) hi-tech cluster development around Science and Technology Industrial Parks (STIPs), Software Parks, and Productivity Promotion Centres (Innovation Clusters); (ii) high-tech business start-up services (Technology Business Incubators); and (iii) financial services for innovation (InnoFund and the Venture Guiding Fund). Indeed, China relied on a full range of financial and non-financial incentives to catch up technologically and develop innovation capabilities (Zhou et al., 2016).

In the deployment of these different measures, the government developed an innovative funding model to support technological innovation. What makes this model particularly innovative is the fact that it integrates several streams of financing, each of them featuring strong policy directionality. The case of the InnoFund sheds some lights on the Chinese approach to funding innovation.

InnoFund was set up in 1999 as a special government R\&D programme to support investments in early stages of technology development. It aims to "facilitate and encourage the innovation activities of small and medium-technology based enterprises (SMTEs) and commercialization of research by way of financing, trying to bring along and attract outside financing for corporate R\&D investment of SMTEs" (InnoFund, 2018). InnoFund has precisely-defined eligibility criteria, and provides different types of financial support targeting different types of companies at different stages of development, from loan interest subsidies to equity investment (Guo et al., 2016). Strict eligibility criteria are critical in bringing selectivity and directionality to the policy scheme.

To be eligible, a project should i) comply with national industrial technology policies; ii) exhibit high potential for social and economic impact; and iii) be competitive in the market. Companies interested in applying for financing should be a business corporation with no more than 500 employees, $30 \%$ of whom must have received higher education. Moreover, the company must show annual R\&D investment of at least $3 \%$ of total sales, with at least $10 \%$ of employees dedicated to R\&D. If the company is operating in an industrial sector with high economies-of-scale potential, it must also exhibit good economic performance.

Among qualifying companies, the following projects are given priority (Zhang and Stough, 2013; Guo et al., 2016):

i. Projects with advanced technology content or independent intellectual property rights and high value added;

ii. Projects established by researchers or oversees returnees interested in commercialising their scientific achievements;

iii. Innovation projects jointly initiated by firms, universities and other research institutions; and

iv. Projects that utilise new and advanced technologies to drive industrial restructuring in traditional sectors and job creation.

A key feature of this programme is the availability of different forms of financing, which allow for targeted industrial financing, acknowledging that companies have different financial needs.

i. Appropriation: start-up capital for small firms created and owned by a researcher with scientific achievement and potential for commercialisation of the innovation. 
ii. Partial subsidies: offered to SMEs engaged in the development of a new product or the setting up of a new production pilot line. The total amount of subsidies is between one and two million renminbi (RMB), with firms required to match the subsidy one-to-one.

iii. Interest-free loans: provided to SMEs for expanding and scaling up the production of innovative products as a substitute for commercial bank funding.

iv. Equity investments: only for investments in advanced technologies, for companies with high capacity and for products with high potential in emerging industries. Equity investments should not exceed $20 \%$ of the registered capital of the firm. In some cases, the government can also provide bank loan insurance to improve the financing terms of commercial banks.

The governance structure of such articulated programmes relies on two levels of governance agencies (Wang, 2013). The InnoFund Administration Centre (IAC) is the central authority under the Ministry of Science and Technology (MOST) and is responsible for: i) the identification of the preferred technology applications and industries, and developing the application guidelines; ii) the ex-ante screening and evaluation of the applications; iii) issuing the contract with the selected firms; and iv) post-investment project assessment. All these funding operations are regulated and monitored by the Ministry of Finance (MOF), which approves the yearly budget, releases funding to the IAC twice annually, and assesses its performance. The MOF and MOST produce joint annual reports on the InnoFund programme, and these are reviewed by the State Council.

At the local level, there are InnoFund offices in each province and these operate under the Provincial Science and Technology Committee. After 2005, the provincial offices received greater power from the Centre and were put in charge of many functions originally performed by the central IAC. The provincial offices had been mere recommendatory bodies before 2005 and, when the central office approved a funding application, the provincial Bureau of Finance was expected to co-fund the allocated funding by $50 \%$. Since 2005 , the provincial committees have increasingly been involved in project selection, and a new application and screening system has been introduced. Local InnoFund offices have been given a 30\% weight in the final decision made by the central IAC office as part of a move towards more decentralisation and greater involvement of local government in decision-making as well as funding (InnoFund, 2018).

The exclusive ex-ante project screening performed by the central IAC presented two main challenges. First, the hierarchical system presented several inefficiencies and was not very transparent. Second, the central offices did not have as good an understanding of local industrial conditions and opportunities as did local offices. As a result of the subsequent decentralisation, the policy process was made more responsive and it became possible to monitor the investments more closely. According to Guo et al. (2016), the system has become even more articulated since 2005, with provincial offices involving more agencies in decisionmaking, and delegating decisions to lower levels. These innovations in the governance settlement have been particularly common in the most advanced regions, including Zhejiang. The governance de-centralisation has also been mirrored by an increasing shift from central transfer to local resources mobilisation. Since 2005, the provincial governments have increased their investments in the InnoFund scheme six-fold.

According to official reports, InnoFund has a 1:11 multiplier effect in terms of inducing external financing and has succeeded in the incubation of world-leading companies, including 
the ICT giant Huawei. After only ten years of operation, 82 of the 273 companies publicly listed on China's SME Stock Exchange were former InnoFund-supported companies.

\subsection{Brazil}

Brazil underwent three major phases of industrial development and policy. The first wave lasted until 1980 and was characterised by extensive state-indicative planning in the areas of sectoral development (e.g. steel, petrochemical and renewable fuels policies) and trade protection (e.g. ad valorem tariffs and law of similarities). Industrial policy was aimed mainly at creating new industrial sectors, shifting away from specialisation in primary commodities, and promoting technology-intensive activities. During the 1980s and 1990s, the Brazilian government shifted away from industrial policy and import substitution in favour of structural adjustment policies and macroeconomic stabilisation. Structural adjustment policies were initially directed at trade liberalisation and the privatisation of public enterprises, while from the mid-1990s they increasingly focused on macroeconomic stabilisation (the 'Real Plan'). The 2000s signalled the return of selective (sector-specific) industrial policies to Brazil. In November 2003, the first Lula government announced the Guidelines for an Industrial, Technology and Foreign Trade Policy (PITCE) aimed at increasing industrial competitiveness by boosting technological development in key sectors (semi-conductors, software, pharmaceuticals and medicines, and capital goods), thus promoting the export of higher valueadded products.

\subsubsection{Breaking into, linking up and back}

The main industrial policy strategy adopted by the Brazilian government between the 1950s and 1970s was based on a protectionist regime structured around ad valorem tariffs. The Law of Similarities (Lei do Similar Nacional) stated that a product could only be imported if it could be proven that a similar product was not produced in Brazil. These measures were intensified during the period from 1960 to 1980 within an import-substitution industrialisation (ISI) strategy. The main aim of this import-substitution strategy was to develop and diversify the domestic production system.

Similarly to China, a number of state-owned enterprises were developed in strategic manufacturing sectors, such as Petrobras (1953), Usiminas (1956), Eletrobras (1962) and Embraer (1969), and the Brazilian Development Bank (BNDES) was established in 1952. Some of these companies and institutions are today the pillars of the Brazilian industrial and financial system. For example, BNDES is the main provider of long-term finance in the country, and one of the biggest in the world measured by assets, equity and disbursement (Ferraz and Coutinho, 2019). Differently from China, however, the Brazilian SOEs did not play the same industrial co-ordination role and did not support the development of a local production system of firms capable of operating both domestically and internationally.

The lack of strategic export-promotion strategies alongside the import-substitution ones did not allow Brazil to link up to global value chains to the same extent as China, and while import substitution allowed for diversification and the development of some local production system linkages, domestic companies did not manage to keep pace with technological change. The macroeconomic crisis and following structural adjustment period further exacerbated the already discontinuous industrialisation pathway in Brazil. 
With the return to industrial policy in the 2000s and the publication of PITCE, a stronger emphasis was put on technology policies and regulations aimed at advancing Brazil's science and technology bases in biotechnology, nanotechnology and biomass/renewable energies. These technologies were considered critical to keep pace with technological changes in the oil and gas, agriculture, and pharmaceutical sectors. The government relied mainly on specific financing programmes, such as Profarma (pharmaceutical) and Prosoft (software), as well as the integration of over 15 sectoral funds to achieve these goals. PITCE also represented an opportunity to address a number of misalignments across the different funding schemes for industrial research - thus "eliminating duplication and scattershot initiatives" (ABDI, 2006:20), as well as re-aligning financial incentives and other complementary legislation concerning intellectual property rights (IPR) and public-private partnerships (PPPs).

The PITCE was followed by an ambitious industrial policy package, called the Productive Development Policy (2008-2011), and the Plano Brazil Maior, launched immediately afterwards in 2011. The Productive Development Policy (PDP) was structured around four challenges: First, maintaining the rate of growth in investment above GDP growth; second, upgrading and diversifying the export basket; third, fostering technological investment and innovation; and fourth, restructuring the industrial system and supporting SMEs and national industrial drivers. The PDP is a complex industrial policy package aligned with specific macrotargets and comprising 425 policy measures (organised into 34 programmes, including both 'sectoral' and 'systemic' actions). The sectoral actions expand PITCE's targets along three main lines: 'Mobilization Programmes in Strategic Areas', 'Programmes to Strengthen Competitiveness', and 'Programmes to Consolidate and Expand Leadership' (Kupfer et al., 2013). The management and implementation of this complex package of interventions has proven extremely challenging, and in some cases the lack of focus has had a negative effect on outcomes.

The Plano Brazil Maior (PBM) was launched in 2011, and signalled the last recent systematic attempt by the Brazilian government at implementing industrial policy for escaping the middleincome trap and achieving sustained growth. The 'strategic map' underpinning the PBM identifies four interdependent guiding principles/objectives. The first is strengthening critical competencies in production capacity, corporate R\&D and industrial skills; second is enhancing value chains through structural upgrading and re-organisation of production systems; third, expanding both domestic and foreign markets beyond specialisation in primary goods; and finally, greater social and environmental sustainability.

Various policy measures have been adopted to implement these guidelines, and in many respects improving Brazilian companies' capabilities in linking up internationally and linking back to the local production system. For example, the PBM strengthens production chains, diversifies/upgrades exports through tax relief, and offers trade remedies (e.g. anti-dumping measures), financing, and loan guarantees for exporters (especially for SMEs). More shortterm measures were also integrated into the plan, as well as systemic and long-term measures like infrastructure development and demand-side interventions (e.g. the government procurement policy was updated).

Despite these ambitious attempts, the implementation and enforcement of industrial policy initiatives since 2000 has lacked continuity and focus, and upgrading coalitions of interests failed to consolidate. As a result, policies did not manage to address the systemic weaknesses of the Brazilian industrial system, especially with respect to its engagement with the global economy. The Brazilian industrial sector did not manage to break into the global markets; in 
fact, after an initial recovery of its manufacturing value addition, industrial performances were stagnant after 2007 and finally started declining again after 2015 (see Figure 4). There is a significant exception in the Brazilian industrialisation journey, however, and this is its successful development of natural resource-processing industries and food production. The development of technological and innovation capabilities in this sector followed a different model from the one described in the China case, and relied mainly on a capillary network of intermediate institutes specialising in technology service provision.

\subsubsection{Keeping pace: The intermediate technology institutions model and the case of Embrapa}

Brazil is today among the top producers and exporters of orange juice, sugar, coffee, soya beans, beef, pork and chicken, as well as having caught up with the traditional big five grain exporters. At the centre of the transformative policy package implemented in Brazil is a network of intermediate institutes called Embrapa, which have fostered technological change, diversification and upgrading in agriculture and farming. Embrapa was founded in 1972 in response to the weaknesses of DNPEA (the National Agricultural Research and Experiment Department). These weaknesses included "researchers' lack of awareness of the basic needs of agriculture and the lack of intradepartmental and external interaction among researchers, extension workers, and farmers (which had led to instances of unproductive duplication of research efforts)" (Beintema et al., 2001:16). Other weaknesses involved "the lack of incentives for researchers (particularly indicated by low salaries), the low level of postgraduate training (12 percent [of] the scientific staff at the time), and finally the insufficient, and often irregular financial resources available" (Beintema et al., 2001:16). Embrapa took over the DNPEA's extensive network of research institutes, covering the main agricultural commodities and regions, experiment stations and existing projects. Agricultural extension services were outside Embrapa's area of intervention and were assigned to another agency, Embrater, which operated until 1991.

The institutional development of Embrapa and its impact on the agricultural sector took several years to manifest. Indeed, building a network of intermediate technology institutes presents several challenges. Institutes need to develop both generic technologies as well as productspecific technology and must invest in the acquisition of infra-technologies, such as testing facilities, and metrology and data systems, without which products cannot be developed or brought to the international markets. Making these hardware technologies work also calls for organisational capabilities and system-process building, such as standards and certification processes. The co-location of institutes in specific regional areas is critical to reflect the heterogeneity of agricultural production and needs. Moreover, internal training (and re-training of the existing workforce) alongside technology transfer and acquisition are needed to build technological capabilities. Finally, incentives must be designed to make the institutes both capable and willing to engage with companies.

During its first decades, Embrapa created a network of national commodity centres and regional centres that focused on major cropping and animal production systems, as well as on eco-regional and national themes. It also increased its internal capabilities by signing partnerships with US universities, which allowed Embrapa's staff to receive postgraduate training. In 1993, the establishment of the Embrapa Planning System (SEP) introduced a systems approach to R\&D planning. This allowed a redefinition and reintegration of the centre's mission, objectives, programmes, human resources, infrastructural needs and priorities. From the late 1980s, agricultural research became increasingly cross-pollinated by research in advanced manufacturing. A good example of this is the satellite monitoring services 
for the acquisition and processing of remote sensor images and field data. The Satellite Monitoring Centre was created in 1989 in an area of $20000 \mathrm{~m}^{2}$ in Campinas, assigned by the Brazilian Army to Embrapa for the development of a special unit focused on territorial management systems and electronic networks for modern agriculture.

Throughout the 1990s, Embrapa was involved in a wide range of activities related to agricultural research and technology, including plant breeding, pest management, food safety, satellite monitoring, sustainable agricultural development, and hunger relief. Crop research activities are carried out at locations around the country to develop crops and varieties that are suited for local conditions (Matthey et al., 2004:10). Investments at the interface between agriculture, biotechnologies and advanced manufacturing included facilities for quality improvement in the meat production chain; an aquaculture laboratory prioritising water quality control, fish feeding and health; an Oenology Laboratory to boost wine production in the northeastern semi-arid region; one of the world's first National Agribusiness Nanotechnology Laboratories, focused on the development of sensors and biosensors for food quality control, certification and traceability and the synthesis of new materials such as polymers and nanostructured materials or thin films and surface-to-manufacture smart packages; and six new walk-in freezers to increase the storage and preservation capacity of the Embrapa Germplasm Bank.

A remarkable achievement of Embrapa has been the claiming of the Cerrado (the Brazilian savannah) for modern agriculture. It introduced "new varieties, cultural practices, zoning, tillage, biological fixation of nitrogen, development of livestock for both meat and milk, vegetables, fruit, irrigation and knowledge of the Cerrado natural resource basis" (Alves, 2010:70). Embrapa's technological efforts were reinforced by government investment, which established new universities and postgraduate courses in all states of the Cerrado region. Similar to Fraunhofers in Germany, Embrapa started playing a critical intermediary role between agricultural and manufacturing R\&D, education, markets, and on-farm agricultural production. It also bridges and transfers knowledge, technical solutions and innovations across different sectors, thus facilitating various forms of inter-sectoral learning (Andreoni \& Chang, 2014). Embrapa has generated and recommended more than nine thousand technologies for Brazilian farmers since its inception in 1973.

The success of this model has more recently led to the establishment of another organisation, focusing on industrial innovation, namely Embrapii (Brazilian Company of Research and Industrial Innovation). This is a Social Organization by the Federal Public Power, which, since 2013, supports technological research institutions by reducing risk in enterprises' RD\&I projects. The non-reimbursable funds managed by Embrapii are invested in innovation projects undertaken between enterprises and Embrapii units and hubs. These units and hubs are technologically focused Innovation Centres with technical capabilities to meet firms' needs for technological solutions and innovations. By 2018, Embrapii had 28 units of excellence centred in the following technology platforms: information and communication technologies, mechanics and manufacturing, materials and chemistry, biotechnologies and applied technologies.

\subsection{South Africa}

With democratisation in 1994, the first post-Apartheid South African government aimed to develop a new industrial policy framework, as seen for instance in the $1995 \mathrm{dti}$ (Department of Trade and Industry) document, Support Measures for the Enhancement of the International 
Competitiveness of South Africa's Industrial Sector. There was a fundamental shift from a 'demand-side' to a 'supply-side' industrial-promotion approach. The former refers to the past practice of promoting certain industries by providing a 'captive market' for producers through tariffs, quotas and other policy measures. Similar to Brazil, the allocation of protection to domestic producers via import substitution was not coupled with export promotion initiatives, and companies failed to break in internationally and link up to global value chains. When 'supply-side' measures were introduced, and more emphasis was given to technological upgrading, policies were mainly horizontal and relied almost exclusively on financial incentives. Different from China, however, the provision of financial incentives for developing industrial competitiveness did not deliver the desired results, due to the lack of the same political economy conditions as well as factors including inadequate scale of industrial policy, rapid trade liberalisation and lack of attention to the need for fundamental structural transformation, as discussed further below.

\subsubsection{Breaking into, linking up and back}

Between 1994 and 2007, industrial policy in South Africa relied mainly on financial incentives for capital investments, $R \& D$ and human resource development. The rationale was to enable producers to increase their domestic and international market share by increasing productivity. These supply-side measures were horizontal in nature, not focusing on any particular segments of manufacturing. Consequently, they were fairly thinly spread (excluding the auto and clothing/textile sectors, which had sector-specific programmes) and had limited impact. As part of this shift, government also undertook a rapid and sweeping trade liberalisation programme (see Erten et al,, 2019).

Rapid trade liberalisation, combined with horizontal industrial policies, comprise a particularly harmful mix of policies, as it can have a dramatic impact on the local production system. Exposure to competitive products from abroad, and a lack of selective instruments to steer needed industrial restructuring, tend to break domestic production linkages and further disconnect potential export-oriented companies from their domestic industrial base. As a result, as shown in Figure 2, the foreign content of domestic value addition doubled during this period and, more than linking back, the local production system was pushed out.

Far from being a comprehensive set of industrial policies, the focus was mainly microeconomic, and little attention was paid to the fundamental structural transformation of the economy during the period 1994 to 2007 . The limited industrial policies during this period were also undermined by austere macroeconomic policies, especially in the late 1990s. These policies did not lead to a substantial deepening of the industrial base, did not promote significant industrial diversification away from mining and minerals, and largely ignored the challenges of an overvalued exchange rate (Zalk, 2011).

Moreover, despite an emphasis on supply-side interventions, these strategies paid relatively limited attention to the much-needed increase in physical and infrastructural investments. South African physical investment had been collapsing since the mid-1980s, from around $30 \%$ of GDP to well under $20 \%$ in the early 1990s (16.7\%). Although investments went up again in the second half of the 1990s, to over $20 \%$, South Africa's investment rates remained far below those typically observed in well-performing middle-income developing countries. During the same periods, Korea, Malaysia, Thailand and China managed an investment/GDP ratio of $40 \%$ (and sometimes even above), and many other developing economies invested around $30 \%$ of their GDP. 
One of the constraints on the effectiveness of industrial policy has been weak policy coordination and alignment with the broader macroeconomic, education, trade and other relevant policy areas (Tregenna, 2011). To a certain extent, this lack of co-ordination reflected the high degree of fragmentation in the political economy situation in the country, with several powerful groups capturing segments of the public sector. Lack of policy co-ordination was exacerbated by conflicting policy goals. Specifically, given the dramatic social tensions and extreme inequalities in South Africa, as well as low growth and lack of structural transformation, industrial policy had to be responsive to multiple policy objectives.

On the one hand, there was a productive transformation policy goal, consisting of the expansion of the manufacturing base and, in particular, of the development of medium- to hightech manufacturing sectors, which tend to be relatively capital-intensive. On the other hand, there was an employment-generation policy goal, consisting of the reduction of unemployment and social tension though the support of those economic sectors that are expected to have a relatively higher job-absorption capacity in the short- to medium-term. Linked to this has been a growing emphasis on advancing black participation in manufacturing through ownership and management, particularly with the Black Industrialist programme launched in 2016.

The National Industrial Policy Framework (NIPF) of 2007, and the associated Industrial Policy Action Plans that followed, marked a new shift in industrial policy in South Africa, in particular from 2009 onwards, when there were increases in allocations to industrial policy and financing. With the Industrial Policy Action Plan 2013-16 (IPAP, 2013), the government attempted to address the trade-off between manufacturing development and employment expansion discussed above. The development of manufacturing industries was recognised as the priority, especially considering that the consumption-driven sectors were growing twice as fast as the productive sectors, with extremely high levels of structural unemployment.

In the 2013/2014 IPAP, the South African government also set a target of increasing research and development expenditure to at least $1 \%$ of GDP and sustaining it there. This important shift was driven by the recognition of the increasing global technological race, and the need for South Africa to build innovation and technological capabilities for more domestic value addition. In view of addressing this challenge, the South African government relied mainly on financial incentives and financing schemes. While these are relatively simpler instruments to design and implement - for example, they do not require the building of a network of institutions as in the case of Embrapa discussed above - they are more difficult to enforce, especially in a highly fragmented political economy context.

\subsubsection{Keeping pace: The matching grant commercialisation model and the case of the Manufacturing Competitiveness Enhancement Programme (MCEP)}

Recent IPAP iterations have structured industrial support measures along two main axes, sector-specific programmes and transversal policies. Sectoral interventions have been broadly divided between sectors that were already supported from 2007 (cluster 1), and additional priorities that include qualitatively new areas of intervention in cluster 2 (e.g. green industries), as well as longer-term targets for the development of capabilities in advanced manufacturing in cluster 3 (e.g. nuclear and aerospace industries). The following sectors were targeted as part of the sector-specific programmes: automotive, medium and heavy commercial, clothing, textile, leather and footwear. Among these vertical interventions, it is possible to roughly distinguish between approaches that generally affected the whole subsector and approaches that more directly affected specific manufacturing firms. Examples of the first group include 
the proposed intervention for biofuels, as well as the pharma sector intervention that aimed to increase production capacity and skills enhancement for the whole subsector (e.g. through new criteria for local procurement in tenders of the Department of Health, as well as the development of a sectoral skills strategy) (see IPAP 2013 to 2016). As for policies affecting specific firms, two programmes were central: (i) the automotive scheme (the Automotive Production and Development Programme $(\text { APDP })^{5}$ ), awarding cash grants to individual firms to invest in productive assets (machinery, equipment, etc.); and (ii) the clothing/textiles scheme (CTCP), providing grants to individual firms to upgrade the skill levels of their labour force or to invest in product and process improvements. The most striking examples of transversal interventions can be found in the finance area. The '12I' Tax Allowance Incentive and the Manufacturing Competitiveness Enhancement Programme (MCEP) both tackled the finance constraints on the firm level, with significant tax allowances (12I) and grants for capital expenditure (MCEP) awarded to individual enterprises.

The MCEP was the key action programme under the industrial financing pillar of IPAP and it aimed at increased industrial competitiveness through better access to financial capital. The programme provided matching grant finance to manufacturing firms to invest in competitiveness enhancement by upgrading production facilities, processes, products and people, and it sought to maximise employment and value-added potential in strategic sectors set out in the IPAP (see IPAP 2012 to 2015). The scheme consisted of seven sub-components, five of which were managed by the dti and two by the Industrial Development Corporation (IDC) ${ }^{6}$

Applicants could apply for one or a combination of the MCEP sub-programmes at company level. Within the dti components of MCEP, firms could apply for a matching grant, and qualifying investment activities included capital equipment for upgrading and expansions; green technology upgrades for cleaner production and resource-efficiency activities; enterprise-level competitiveness improvement activities for new or increased market access, product and process improvements; related skills development; and conducting feasibility studies. One component allowed for clusters of firms to apply for a grant for their collective efforts.

The programme was of significant size, and was scheduled to run over five years (2012 to 2017). In terms of sectoral distribution, the scheme was introduced as a horizontal intervention and in general allowed most manufacturing firms to apply, although sectors that are covered by similar sector-specific grant schemes (e.g. automotive and textiles) were usually not eligible. However, actual approvals show a strong sectoral focus on the agro-processing (36 grants worth R383 million), metals (62 grants worth R259 million) and chemicals (26 grants worth R117 million) sectors in 2012/13. The three sectors jointly accounted for $77 \%$ of the volume of all grants in this period (IDAD, 2013).

While the dti regularly engages in the implementation of financing schemes for manufacturing firms such as the MCEP itself, e.g. for the provision of capital expenditure grants, South Africa also has two dedicated industrial financing institutions (in addition to other non-industrial development finance institutions). Firstly, the Industrial Development Corporation (IDC) was

\footnotetext{
5 The APDP replaced the earlier Motor Industry Development Programme (MIDP) in 2013. See, for example, Barnes and Morris, 2008; Barnes, 2013; and Black, 2009, 2017 on industrial development and industrial policy related specifically to the auto sector in South Africa.

${ }^{6}$ The IDC components are a pre- and post-dispatch working capital loan facility and the Industrial Policy Niche Projects Fund.
} 
set up in 1940 to promote economic growth and industrial development and is owned by the South African government. It provides loan and equity funding to private industrial firms. Secondly, the Export Credit Insurance Corporation (ECIC), which is a state-owned agency established in 2001. The ECIC facilitates South African export trade by underwriting export credit loans and investments outside the country.

Emphasising the strategic importance of these institutions, several IPAPs argued that, given the scale of competitor banks such as the China Development Bank and the Brazilian BNDES, these institutions should secure agreement on a collaborative approach to identify and unlock opportunities for support to South African and African manufacturers (see the 2014/15 and 2016/2017 IPAP).

In sum, the financial support measures to address the middle-income technology trap in South Africa consist of two main legs: 1) grant schemes administered by the dti, and 2) the provision of (working capital) loans, as well as equity and debt financing, by the IDC. This two-pronged approach follows a certain logic. The matching grant schemes are put in place to mitigate the major constraint of access to finance quickly by injecting capital directly into manufacturing firms. However, as this approach will only relieve the financial constraint facing the manufacturing sector temporarily, this needs to be complemented by actions to increase access to finance in the longer term. The IDC and other industrial financing institutions could eventually assume this role, but this would require changes in both the scale and nature of their financing.

Given the existing misalignments and fragmentation in the matching grant scheme, as well as the lack of clear parameters for selecting firms and enforcing the policy, the last iterations and revisions of the IPAP have pointed to the need for a 're-calibration' of existing dti incentives, with the ultimate aim of a more targeted approach for financial incentives. The 2013/2014 IPAP also recognises the existence of intervention gaps and misalignments along the innovation value chain, and the need to review and restructure existing programmes within the Department of Science and Technology's National Research and Development Strategy. In particular, the 2014/2015 to 2016/2017 IPAP stresses the importance of: (i) supporting large research and development programmes (cross-cutting, innovative and sustainable) in knowledge-intensive areas within the Emerging Industries Action Plan (EIAP); (ii) supporting both existing and new technology-based SMEs to access the technological infrastructure (such as incubation services) and innovation support programmes; and (iii) addressing industrial scalability and commercialisation challenges within a comprehensive technologycommercialisation strategy.

By mapping funding schemes and supporting programmes, the South African government is aiming to address, in a selective way, those specific funding gaps, but also dysfunctional overlaps and duplications that result in bottlenecks or effort-wasting along the innovation journey. Indeed, this mapping exercise constitutes a fundamental step in redesigning the technological infrastructure of South Africa in order to improve its effectiveness in supporting industrial and technological upgrading. While expanding the production capacity of the country is critical in order to reach efficiency-scale and high-volume production, the application of innovative technologies in production and product systems and sub-components development is critical to allow South Africa to capture increasing value from international trade.

4. Comparative analysis and industrial policy lessons 
Middle-income countries develop along very distinctive structural trajectories. In some cases, some countries are considerably more successful than others, although all of them experience some degrees of success and failures. These differences are shaped partly by the different types of policy instruments, institutions and governance models they use in addressing their industrialisation challenges as they reach, and attempt to surpass, middle-income status. The three case studies documented here present some common features, as well as three distinctive ways of promoting technological upgrading beyond the middle-income technology trap.

\subsection{Commonalities}

\subsubsection{Variety of industrial policy instruments and institutions}

The middle-income countries we focus on - China, Brazil and South Africa - have all relied on a variety of industrial policy instruments and institutions throughout their development journey. These policies and institutions play different - but also highly complementary functions in terms of allowing the middle-income country in break into the global market, linking up to global value chains, linking back to the local production system, and keeping pace with technological change. Table 1 summaries the main instruments adopted by the three countries in this regard.

Table 1: Industrial policy to escape the middle-income technology trap

\begin{tabular}{|c|l|c|c|c|}
\hline Challenge & Industrial policy & China & Brazil & $\begin{array}{c}\text { South } \\
\text { Africa }\end{array}$ \\
\hline \multirow{4}{*}{ Breaking into } & Selective sectoral promotion policies & $\mathrm{X}$ & $\mathrm{X}$ & $\mathrm{X}$ \\
\cline { 2 - 5 } & Building national champions & $\mathrm{X}$ & $\mathrm{X}$ & \\
\cline { 2 - 5 } & Industrial consolidation (e.g. M\&A) & $\mathrm{X}$ & & \\
\cline { 2 - 5 } & Export-promotion services & $\mathrm{X}$ & & \\
\cline { 2 - 5 } & Development banks and finance & $\mathrm{X}$ & $\mathrm{X}$ & \\
\hline \multirow{5}{*}{ Linking up } & FDI policy & $\mathrm{X}$ & $\mathrm{X}$ & $\mathrm{X}$ \\
\cline { 2 - 5 } & Joint ventures and technology transfer & $\mathrm{X}$ & $\mathrm{X}$ & $\mathrm{X}$ \\
\cline { 2 - 5 } & Export incentives & $\mathrm{X}$ & $\mathrm{X}$ & $\mathrm{X}$ \\
\cline { 2 - 5 } & Export-promotion zones & $\mathrm{X}$ & & \\
\cline { 2 - 5 } & Export finance & $\mathrm{X}$ & & \\
\hline \multirow{5}{*}{ Linking back } & Selective trade policy & $\mathrm{X}$ & $\mathrm{X}$ & $\mathrm{X}$ \\
\cline { 2 - 5 } & Local content policy & $\mathrm{X}$ & $\mathrm{X}$ & $\mathrm{X}$ \\
\cline { 2 - 5 } & Joint ventures and technology transfer & $\mathrm{X}$ & \\
\cline { 2 - 5 } & Capital investment finance & $\mathrm{X}$ & $\mathrm{X}$ & $\mathrm{X}$ \\
\cline { 2 - 5 } & Technical and vocational training & $\mathrm{X}$ & $\mathrm{X}$ & \\
\cline { 2 - 5 } & Technology intermediate institutes & $\mathrm{X}$ & $\mathrm{X}$ & $\mathrm{X}$ \\
\hline \multirow{3}{*}{ Keeping pace } & R\&D incentives & $\mathrm{X}$ & & \\
\cline { 2 - 5 } & Matching grants and subsidies & $\mathrm{X}$ & $\mathrm{X}$ & $\mathrm{X}$ \\
\cline { 2 - 5 } & Hybrid finance and soft loans & & & \\
\cline { 2 - 5 } & Technology intermediate institutes & $\mathrm{X}$ & \\
\cline { 2 - 5 } & Joint ventures and technology transfer & $\mathrm{X}$ & $\mathrm{X}$ & \\
\hline
\end{tabular}

Source: Authors

While many of these instruments are used across all these countries - and indeed many other middle-income countries - even when they are similar there is heterogeneity in terms of specific policy and institutional design features. Despite these differences, our case studies 
have shown two broad industrial policy models. These are industrial policy relying on financial incentives, rents and other monetary transfers on the one hand (this was detailed in the case study of the InnoFund in China and the MCEP in South Africa); and industrial policy relying on the provision of production, technological and industrial services, including the provision of intermediate technologies, training and market services for export on the other (this was highlighted in the case study of Embrapa in Brazil).

\subsubsection{Industrial policy alignment and co-ordination}

Independently of the technology policy model adopted and its integration into a broader industrial policy package, all three countries had to align their industrial policy with the evolving needs of their industrial systems. Specifically, following the structural cycles of technological change and the reconfigurations in the industrial organisation of different sectors, and in response to changes in the global industrial landscape, the governments of China, Brazil and South Africa had to change their policy approach and targets. At different points in time, approaching middle-income status has been concomitant with a shift towards increasing investments in the development and accumulation of technological and innovation capabilities. Indeed, when a middle-income country exhausts its traditional developing-country advantages, government has to step up its industrialisation targets and equip the industrial system with more instruments to grab hold of and climb the global technology ladder. The commitment of resources becomes increasingly demanding, especially in a country such as South Africa, in which industrial policy investments are inadequately complemented by sustained private investments.

The need for designing and co-ordinating different institutions and levels of governance is another common feature of the three middle-income countries discussed here. Within the public sector, the government is articulated in different ministries, departments and agencies operating at both the national and sub-national levels. However, in some cases, public departments and agencies diverge in their interests - for example in the case of national and more local institutions - or might operate in silos, sometimes entering into fights to control resources. The ongoing need to co-ordinate multi-governance structures and to avoid risks of institutional and policy fragmentation is common across all three middle-income countries studied here, although some of them are more successful than others in implementing functioning governance models. Examples are the decentralised model adopted by China through the InnoFund programme, and the complex institutional arrangements adopted by Embrapa to manage a complex web of technology intermediary centres across a vast country like Brazil. The South African case has shown the risks of governance fragmentation, resulting both from limited targeting in policy design and the existence of different conflicting claims and diverging private interests. Related to this, a key difference between the three country cases lies in the extent to which industrial policy has been co-ordinated with other relevant policy domains macroeconomic policy, policies around R\&D and innovation, skills development and so on.

\subsubsection{Industrial policy feasibility and enforceability}

Another common feature is the challenge that all countries face in designing policies that are feasible and enforceable by the country's institutions. The Chinese case, in particular, shows the importance of embedding principles of enforcement in the early stages of policy design. The meticulous design and balance of carrots and sticks in innovation funds, and the mixing of different types of grants, interest-free loans and long-term loans, and public procurement, demonstrate a complex system of incentives that target and match firms' different capabilities. 
Similarly, the design and coherent alignment of incentives represent a significant challenge in the case of South Africa, in some cases posing questions about the real additionality of these interventions.

In all cases, the relationship between the government and the private sector matters. Experience shows the importance of continuous dialogue and exchange of information between the two if the policies are going to be well informed and relevant. However, it is also important that the government does not become beholden to particular industrial interests, and thus face the danger of 'capture'. Evans (1995) has described this point with the notion of 'embedded autonomy', meaning that government needs to have roots in society ('embeddedness'), but must also have its own will and power ('autonomy') in order to be effective in its interventions. In understanding the relationship between the government and the private sector, it is critical to start from assessing the distribution of organisational power in both the public and private sectors - thus, the countries' "political settlement" (Khan, 2010) - and the relationship between powerful organisations (including elites and intermediate groups) operating in both (and at the interface between) the public and private sectors. The analysis of a country's political settlement allows for the assessment of the feasibility of certain policy interventions, and thus the extent to which a certain policy instrument can be implemented and enforced in a given political settlement.

Industrial policy for the building of productive capabilities can play a central role in transforming the private sector and moving towards a more balanced distribution of power. By mobilising resources towards productive forces in the private sector, and creating incentives for technological upgrading and for the building up of the local production system, industrial policy can make productive investments feasible and profitable. However, to be effective, the design, implementation and enforcement of industrial policy must take into consideration what specific resources and incentives the different players along different sectoral value chains will need to become more productive.

\subsection{Differences}

Despite all these commonalities, the three case studies also point to three very different policy approaches, as highlighted in Figure 5.

The experience of China stresses, inter alia, the importance of long-term commitment and a staged approach to industrial transformation, especially with respect to technological advancement in the manufacturing sector. InnoFund is presented as a successful case of a funding scheme for technology policy supporting the early stages of industrial innovation and technology development.

The Brazilian case highlights the importance of promoting the development of public technology intermediaries who support the absorption, adaptation and diffusion of technologies, especially in the intermediate stages of technology development. The Embrapa case study is particularly important for middle-income countries, as it suggests opportunities for technological development and value addition in both advanced technologies and at the interface between the agriculture and manufacturing sectors.

The South Africa case study points to the importance of boosting investments in technology deployment and production operations, especially when the private sector is reticent to sustain high rates of investment in fixed capital and technologies. The investment in the later 
technology-development stage is also important for stimulating technology upgrading by technology transfer and absorption, especially in cases where the basic science and research is limited in scale.

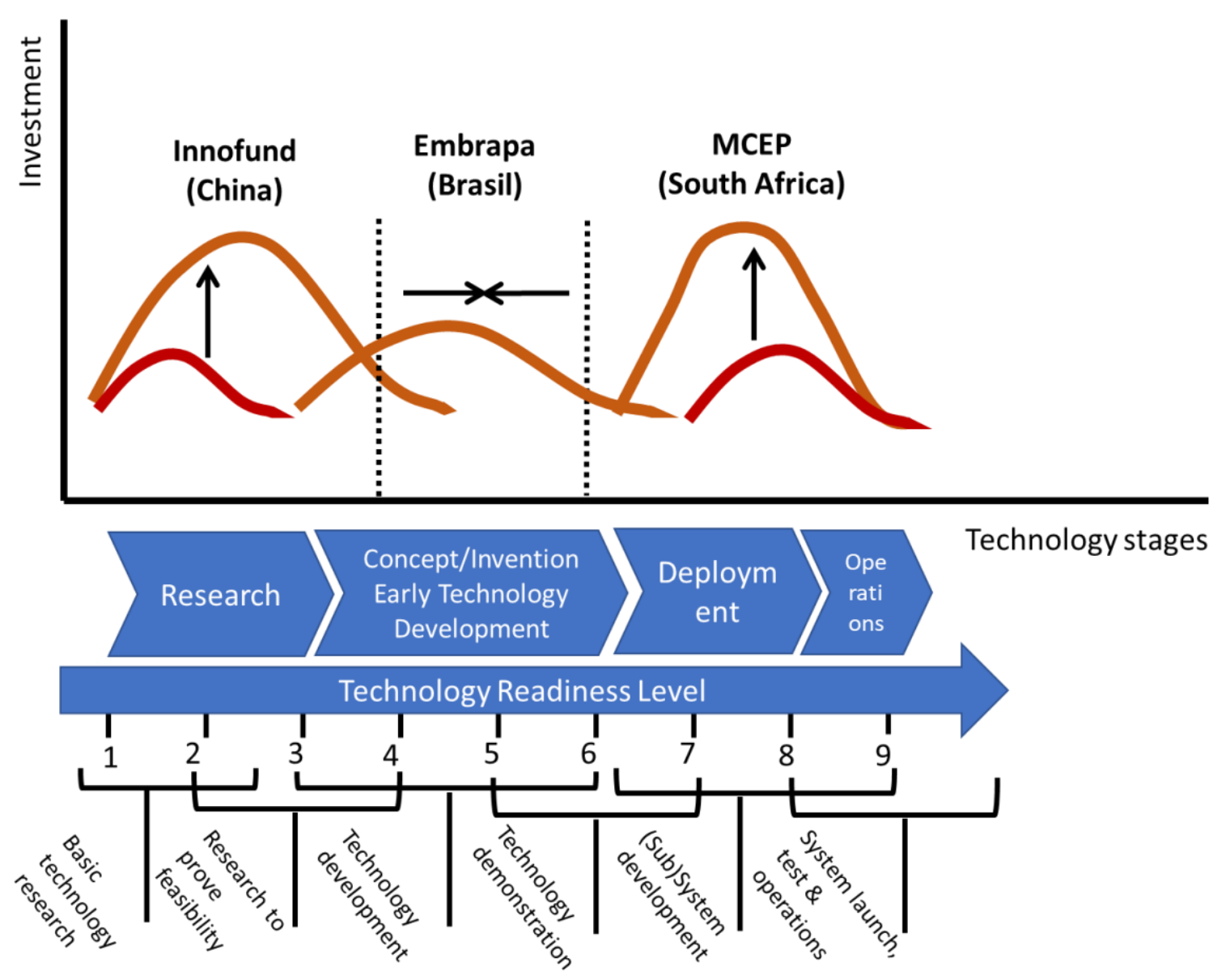

Figure 5: Keeping pace with technological change and innovation: policy initiatives Source: Authors

The country cases and the different models reviewed here point to three important policy implications, with particular relevance for middle-income countries.

First, there are significant opportunities for value addition and technological development across different sectoral value chains, including agro-business value chains. For example, the innovative industrialisation of agriculture opens new venues for increasing productivity, upgrading global markets and diversifying. However, in order to capture these opportunities, public technology intermediaries must provide key technology and product services to reach product quality standards, and transform agricultural activities into highly productive industrial processes.

Second, the promotion of technological upgrading in manufacturing industries cannot be done simply by jumping to frontier technologies. The China case study, in particular, emphasises how the building of a solid productive and technological capability foundation over time is a precondition for innovation across several industrial fields. This, of course, does not mean that 
change must be incremental or based on existing static comparative advantages; the experience of China demonstrates the possibilities of leapfrogging, but with a solid base built up through deliberate policy interventions. A related lesson is that institutions promoting technological innovation have to change over time to respond to the changing innovation challenges firms face in the fast-changing global landscape.

A third policy lesson is that, to increase value addition and value capturing in the domestic economy, countries need to target the development of their local production systems - what we called here 'linking up and back'. The building of integrated supply chains in the domestic economy gives countries sustained industrial and productivity growth. Therefore, industrial policy focusing for example on the attraction of a multinational or on the setting up of an export-promotion zone must be fully co-ordinated with other policy measures that support industrialisation. The Chinese success in linking up and back underscores the importance of sustaining industrial development, with multiple sets of interventions reinforcing each other in a co-ordinated manner. The development of the local production system as a strategy to move beyond the middle-income technology trap also requires engaging with technological change, especially taking into consideration the multiple cross-system applications of modern technologies.

While manufacturing remains a cornerstone for re-industrialisation and technological development in premature de-industrialisers like South Africa and Brazil, new value-addition opportunities can be found at the interface with other sectors and the intersection of different technology systems. Well-co-ordinated and coherent industrial policy packages are critical in shaping new structural trajectories beyond the middle-income technology trap.

\section{Conclusion}

While an extensive literature explores various aspects of the middle-income trap, here we propose the concept of a middle-income technology trap, referring to structural and institutional configurations that are not conducive to increasing domestic value addition and to sustained industrial and technological upgrading in middle-income economies. This trap is associated with what we identify as the triple challenges of 'breaking into' the global economy, 'linking up' into global value chains while simultaneously 'linking back' to the local production system, and 'keeping pace' with technological change.

We explore these issues through case studies of industrial policy interventions in three prominent middle-income countries in Asia (the InnoFund model in China), Latin America (the Embrapa system in Brazil) and Africa (the MCEP in South Africa). In each case, we reflect on the specific structural configuration challenges, and assess the diverse institutional and industrial policy responses adopted. We characterise the InnoFund model from China an example of a 'funding innovation model' and hybrid financial solutions; the Embrapa system in Brazil exemplifies an intermediate technology institution model supporting product, process and technology scaling-up stages; while we see the MCEP programme in South Africa as an example of a matching grant commercialisation approach, focuses primarily on the later stages of technology absorption and development. These case studies illustrate the diversity of ways in which middle-income countries have attempted to 'break in', 'link up' and 'link back', and 'keep pace', and to avoid or escape from a middle-income technology trap.

These case studies have shed light on the range of industrial policy instruments utilised, within what we characterise as two broad industrial policy models. Firstly, approaches based on 
financial incentives, rents and other monetary transfers, with the InnoFund in China and the MCEP in South Africa representing very different examples within this. Secondly, approaches based on the provision of production, technological and industrial services, including of intermediate technologies, training and market services to promote exports, as in the case of Embrapa in Brazil. In all three cases, countries faced the imperative of aligning their industrial policy with the evolving needs of their industrial systems, although they achieved this with varying degrees of success. This needs to be understood in the context of countries political economy, with particular differences between China on the one hand, and Brazil and South Africa on the other.

The diversity in the experiences of these three cases of middle-income countries is clear. This is broadly in terms of their industrial policies and in their industrialisation and growth trajectories, and more specifically in terms of their approaches to promoting technological upgrading beyond the middle-income technology trap, including in the technological stages that are primarily targeted for support.

This analysis has important policy implications, in particular for middle-income countries seeking to avoid a middle-income technology trap and the middle-income trap more broadly. We have drawn attention to three specific policy issues. Firstly, that there are considerable opportunities for upgrading in value chains, including in agro-business value chains, but this requires industrial policy support (including substantial support in key technological and product services) and the 'industrialisation of at least some agricultural activities. Secondly, the importance of building depth of productive and technological capabilities to support innovation and upgrading. Thirdly, the need for countries to 'link up' and 'link back' through the development and integration of their local production systems, including through technological upgrading as a basis for sustained productivity growth. All of these require industrial policies that are flexible and dynamic, that are appropriate for countries' specific political economic and other characteristics, that go beyond the manufacturing sector, that support innovation and technological upgrading as integral aspects of industrial development, and that are well co-ordinated with other policy domains. 


\section{References}

ABDI (Brazilian Agency for Industrial Development), 2006. An Industrial Policy for Brazil. ABDI, Brasilia.

Alves, E., 2010. Embrapa: A Success Story of Institutional Innovation. Brazilian Agricultural Research Corporation, Brasilia.

Andreoni, A., 2014. Structural learning: Embedding discoveries and the dynamics of production. Struct. Change Econ. D. 29, 58-74.

Andreoni, A., 2018. The architecture and dynamics of industrial ecosystems. Camb. J. Econ. $42,1613-1642$.

Andreoni, A., 2019. A generalized linkage approach to local production systems development in the era of global value chains, with special reference to Africa, in: Kanbur, R., Noman, A., Stiglitz, J. (Eds.), Quality of Growth in Africa. Columbia University Press, New York.

Andreoni, A., Chang, H.-J., 2014. Agricultural policy and the role of intermediate institutions in production capabilities transformation: Fundacion Chile and Embrapa in action. Paper presented at the DRUID Annual Conference, Copenhagen, Denmark.

Andreoni, A., Chang, H.-J., 2019. The political economy of industrial policy: Structural interdependencies, policy alignment and conflict management. Struct. Change Econ. D. 48, $136-150$.

Andreoni, A., Tregenna, F., 2019 Beyond the inverted U: The changing nature and structural heterogeneity of premature deindustrialisation. International Workshop: The future of industrial work: New pathways and policies of structural transformation? UNIDO, Vienna, Austria, 19-20 September.

Arias, M.A., Wen, Y., 2015. Trapped: Few developing countries can climb the economic ladder or stay there. The Regional Economist, Federal Reserve Bank of St. Louis.

Barnes, J., Morris, M. 2008. Staying alive in the global automotive industry: What can developing economies learn from South Africa about linking into global automotive value chains? The European Journal of Development Research, 20(1), 31-55.

Barnes, J., 2013. Capital structure of the South African automotive industry: Historical perspectives and development implications. Transformation: Critical Perspectives on Southern Africa, 81(1), 236-259.

Beintema, N.M., Ávila, A.F.D., Pardey, P.G., 2001. Agricultural R\&D in Brazil: Policy, Investments and Institutional Profile. IFPRI, Embrapa and Fontagro, Ago, Washington, DC.

Berger, S., 2013. Making in America. MIT Press, Cambridge.

Black, A. 2009. Location, Automotive Policy, and Multinational Strategy: The Position of South Africa in the Global Industry since 1995. Growth and Change, 40: 483-512. 
Black, A., 2017. Trade Liberalization, Technical Change and Firm Level Restructuring in the South African Automotive Component Sector. Institutions and Economies, [S.1.], 173-202.

Block, F., M. Keller., 2009. State of Innovation. The US' Government Role in Technology Development. Routledge, Oxford.

Bresser-Pereira, L.C., Araujo, E.C., Peres, S.C., 2020. An alternative to the middle-income trap. Struct. Change Econ. D. 52, 294-312.

Chang, H.-J., Andreoni, A., 2020. Industrial policy in the 21st century. Dev. Change. https://doi.org/10.1111/dech.12570

Doner, R., Schneider, B.R., 2016. The middle income trap. More politics than economics. World Polit. 68, 608-644.

Doner, R., Schneider, B.R., 2019. Technical education in the middle income trap: Building coalitions for skill formation. J. Dev. Stud. https://doi.org/10.1080/00220388.2019.1595597

Dorn, J., Cloutier, T., 2013. Report on Chinese industrial policies. http://bucket-gw-cni-staticcmssi.s3.amazonaws.com/legacy/app/conteudo 18/2013/04/12/3558/2013041217403135943 2 u.pdf (accessed 23 July 2018).

Erten, B., Leight, J., Tregenna, F., 2019. Trade liberalization and local labor market adjustment in South Africa. J. Int. Econ. 118, 448-467.

Evans, P., 1995. Embedded Autonomy: State and Industrial Transformation. Princeton University Press, Princeton.

Felipe, J., 2012. Tracking the Middle-Income Trap: What is It, Who is in It, and Why? Part 1. Asian Development Bank (ADB) Economics Working Paper Series No. 306, Manila, Philippines.

Felipe, J., Kumar, U., Galope, R., 2017. Middle-income transitions: Trap or myth? J. Asia Pac. Econ. 22(3), 429-453.

Ferraz, J., Coutinho, L., 2019. Investment policies, development finance and economic transformation: Lessons from BNDES. Structural Change and Economic Dynamics, 48, 86102.

Ferri, G., Liu, L., 2010. Honor thy creditors beforan thy shareholders: Are the profits of Chinese state-owned enterprises real? Asian Econ. Pap. 9(3), 50-71.

Gereffi, G., 2013. Global value chains in a post-Washington consensus world. Rev. Int. Polit. Econ. 21(1), 9-37.

Gill, I., Kharas, H., 2008. An East Asian Renaissance. World Bank, Washington, DC.

Guo, D., Guo, Y., Jiang, K., 2016. Government-subsidized R\&D and firm innovation: Evidence from China. Res. Policy 45(6), 1129-1144. 
Hall, B., Rosenberg, N. (Eds.), 2010. Handbook of Economics of Innovation. Elsevier, Amsterdam.

Haraguchi, N., Cheng, C.F.C., Smeets, E., 2017. The importance of manufacturing in economic development: Has this changed? World Dev. 93, 293-315.

Huang, Y., 2003. Selling China: Foreign Direct Investment During the Reform Era. Cambridge University Press, Cambridge.

IDAD (2013) The Incentive Development and Administration Division Annual Report, South Africa. https://www.thedti.gov.za/parliament/Annual_Report.jsp

Im, F.G., Rosenblatt, D. 2013. Middle-Income Traps: A Conceptual and Empirical Survey. Policy Research Working Paper No. 6594, World Bank, Washington, DC.

InnoFund (2018) Annual Reports, available at: http://www.InnoFund.gov.cn/

Kang, N., Paus, E., 2019. The political economy of the middle income trap: The challenges of advancing innovation capabilities in Latin America, Asia and beyond. J. Dev. Stud. doi:10.1080/00220388.2019.1595601

Khan, M.H., 2010. Political Settlements and the Governance of Growth-enhancing Institutions. Mimeo, SOAS University of London, London.

Klingler-Vidra, R., Wade, R., 2019. Science and technology policies and the middle-income trap: Lessons from Vietnam. J. Dev. Stud. https://doi.org/10.1080/00220388.2019.1595598

Kupfer, D., Ferraz, J., Marques, F., 2013. The return of industrial policy in Brazil, in: Stiglitz, J., Lin, J. (Eds.), The Industrial Policy Revolution I. Palgrave, Basingstoke, pp. 155-173.

Lee, K., 2013. Schumpeterian Analysis of Economic Catch-up: Knowledge, Path-creation and Middle-income Trap. Cambridge University Press, Cambridge.

Lee, K., Ramanayake, S., 2018. Adding-up problem and wage-productivity gap in exports of developing countries: A source of the middle-income trap. Eur. J. Dev. Res. 30, 769-788.

Lee, K., Szapiro, M., Zhuqing, M., 2017. From global value chains (GVC) to innovation systems for local value chains and knowledge creation. Eur. J. Dev. Res. 30(3), 424-441.

Lin, J.Y., 2017. Industrial policies for avoiding the middle-income trap: A new structural economics perspective. J. Chin. Econ. Bus. Stud. 15(1), 5-18.

Link, A., Scott, J., 2011. Public Goods, Public Gains. Calculating the Social Benefits of Public R\&D. Oxford University Press. Oxford.

Lo, D., Wu, M., 2014. The state and industrial policy in Chinese economic development, in: Salazar-Xirinachs, J.M., Nubler, I., Kozul-Wright, R. (Eds.), Transforming Economies. ILO, Geneva, pp. 307-326. 
Mankins, J., 2009. Technology readiness assessments: A retrospective. Acta Astronaut. 65(910), 1216-1223.

Matthey, H., Fabiosa, J., Fuller, F., 2004. Brazil: The future of modern agriculture? MATRIC Briefing Paper No. 8, Iowa State University, Amses, Iowa.

Milberg, W., Winkler, D., 2013. Outsourcing Economics. Global Value Chains in Capitalist Development. Cambridge University Press, Cambridge.

Nolan, P., 2001. China and the Global Economy: National Champions, Industrial Policy, and the Big Business Revolution. Palgrave, New York.

OECD, 2018. OECD trade in value added database. https://www.oecd.org/sti/ind/measuringtrade-in-value-added.htm (accessed 1 June 2017).

Paus, E., 2019. Innovation strategies matter: Latin America's middle-income trap meets China and globalisation. J. Dev. Stud. https://doi.org/10.1080/00220388.2019.1595600

Ponte, S., Gereffi, G., Raj-Reichert, G., 2019. Handbook on Global Value Chains. Edward Elgar, Cheltenham.

Raj-Reichert, G., 2019. Global value chains, contract manufacturers, and the middle-income trap: The electronics industry in Malaysia. J. Dev. Stud. https://doi.org/10.1080/00220388.2019.1595599

Roehrig, M.F., 1994. Foreign Joint Ventures in Contemporary China. St. Martin's Press, New York.

Sen, K., Tyce, M., 2019. The elusive quest for high income status - Malaysia and Thailand in the post-crisis years. Struct. Change Econ. D. 48, 119-135.

Sutherland, D., 2003. China's Large Enterprises and the Challenge of Late Industrialisation. RoutledgeCurzon, London.

Tassey, G., 2007. The Technology Imperative. Edward Elgar, Cheltenham.

Tregenna, F., 2009. Characterising deindustrialisation: An analysis of changes in manufacturing employment and output internationally Camb. J. Econ. 33(3), 433-466.

Tregenna, F., 2011. A new growth path for South Africa? Rev. Afr. Polit. Econ. 38(130), 627635.

Wade, R., 2016. Industrial policy in response to the middle income trap and the third wave of the digital revolution. Glob. Policy 7(4), 469-480.

Whittaker, D.H., Sturgeon, T., Okita, T., Zhu, T., 2020. Compressed Development. Oxford University Press, Oxford. 
World Bank, 2013. China 2030: Building a Modern, Harmonious, and Creative Society. World Bank, Washington DC.

World Bank, 2018. The World Bank in the Middle Income Countries. https://www.worldbank.org/en/country/mic (accessed 1 June 2017).

Zalk, N., 2011. South African post-Apartheid policies towards industrialization: Tentative implications for other African countries, in: Noman, A. Botchwey, K., Stein, H., Stiglitz, J. (Eds.), Good Growth and Governance in Africa: Rethinking Development Strategies. Oxford University Press, Oxford.

Zhang, T., Stough, R. 2013. Eds. Entrepreneurship and Economic Growth in China, New. Jersey, London, Singapore: World Scientific Publishing.

Zhou, Y., Lazonick,W. and Sun, Y. 2016. China as an Innovation Nation. Oxford University Press, Oxford.

Wang, E. 2013. Entrepreneurship finance - InnoFund, in: Zhang, T., Stough, R. 2013. Eds. Entrepreneurship and Economic Growth in China, New. Jersey, London, Singapore: World Scientific Publishing. 